PNL-2724

UC-41

\title{
Vertical Contamination in the Unconfined Groundwater at the Hanford Site, Washington
}
P. A. Eddy
D. A. Myers
J. R. Raymond

August 1978

Prepared for the U.S. Department of Energy under Contract EY-76-C-06-1830

Pacific Northwest Laboratory Operated for the U.S. Department of Energy by

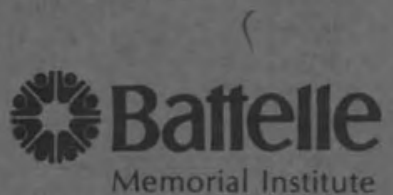


NOTICE

This report was prepared as an account of woik sponsored by the United States Genvernmert. Nicitiver the United States nor the Department of Energy. nor any of their emolovees. nor any of their coniractors. subccutractor; or their employees, makes any warsanily. express or implied. or assumes any les,ai liability or responsibility for the accuracy, completeness or usefulness of any information, dopdratus, product or process disclosed, or reoresens hat its use woulc not intringe privately owned right.

The views, opinions and condusions contained in this report are those of the contrattor and do not fecessarly represent those of the United States Government or the United States Dupartment or Energy

\author{
PACIFIC NORTHINEST LABORATORI \\ uperaied bv \\ BATTELLE \\ for the \\ UNITED STATES DEPARTMENT OF ENERCY \\ Under Contratt EY-Th-C-06-1a30
}
Printen in the Gnised States uf Amerca Available trom
Watisnai Technical Intormatian Se.vize
Unitisd sares Denartment of Cutima ze
3255 Pot Rovat Rore
Spr nitielet, Virginia $2215 i$

Price: "rintad Copy 5 _.....: Miccotiche Sjiciv

\begin{tabular}{|c|c|}
\hline "Japtes & $\begin{array}{c}\text { VT:5 } \\
\text { Selirg Frice }\end{array}$ \\
\hline and ars & jo or. \\
\hline $225 \cdot 250$ & $8: 1.00$ \\
\hline 351.275 & $\$ 9.15$ \\
\hline $175-100$ & 56.00 \\
\hline$\cdot 125$ & 56.50 \\
\hline 5.150 & 57.35 \\
\hline $1 / 3$ & 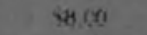 \\
\hline$\because 5-16$ & $\$ 9.00$ \\
\hline $394-7-5$ & 59.75 \\
\hline $226 \cdot i 50$ & $j 9.50$ \\
\hline & S10,7e \\
\hline & $511: x$ \\
\hline
\end{tabular}




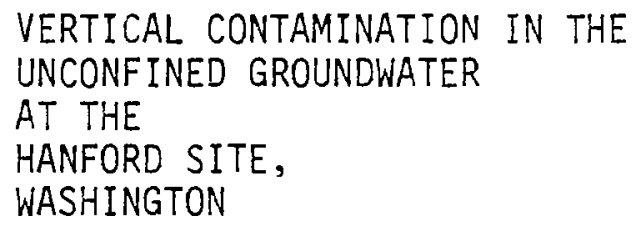
P. A. Eddy
D. A. Myers
J. R. Raymond

August 1978

Prepared for the U.S. Department of Energy Under Contract EY-76-C-06-1830 
SUMMARY

Disposal to the ground at Hanford of large volumes of low- and intermediate-level wastes in the local unconfined groundwater flow system has raised concern about the movement and distribution of this waste. Previous work produced information on the horizontal movement of the waste, but little or no information exists on its vertical distribution within the unconfined groundwater flow system.

In 1975 Phase I of a study was started to determine vertical distribution of contaminants in three existing wel1s 699-28-40, 699-31-31, and 699-37-43). Because of negative results, only one well that produced positive results (699-31-31) was chosen for Phase II. Phase II consisted of tests conducted on this well by a testing company, with samples cross-checked by two different laboratories. Phase III was a cooperative study with Rockwell Hanford Operations, which included the installation, testing, and sampling of piezometers. The data were then analyzed using predictive codes and models in order to determine if vertical movement did occur.

The present groundwater flow system shows some vertical contamination. However, concentrations are relatively higher near the surface of the flow system, indicating possible radial flow patterns from the groundwater mounds known to have developed under the chemical processing area disposal sites. Upward flow from deeper aquifers may be di?uting the contaminant and masking a possible downward migration of contaminants. 


\section{CONTENTS}

SUMMARY

INTRODUCTION

CONCLUSIONS AND RECOMMENDATIONS.

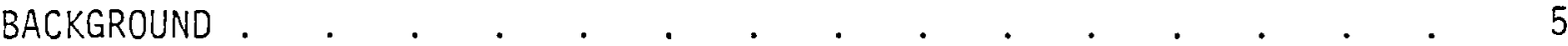

GROUNDHATER MONITORING PROGRAM . . . . . . . . . . . 5

SAMPLING AND ANALYSIS . . . . . . . . . . . . . . . 7

WELL MAINTENANCE PROGRAM! . . . . . . . . . . . . . . . . . 7

METHODOLOGY. . . . . . . . . . . . . . . . . 9

PHASE I . . . . . . . . . . . . . . . 9

PHASE II . . . . . . . . . . . . . . . . . 9

PHASE III . . . . . . . . . . . . . . . . . . . . . . 14

Rockwell Hanford Operations (RHO) Work . . . . . 15

Study Description. . . . . . . . . . . 18

REFERENCES . . . . . . . . . . . . . . . . . . . . . 2 . 2 .

ACKNOWLEDGMENTS. . . . . . . . . . . . . . . . . . . . . 22

APPENDIX - GRAPHS OF SELECTED INELLS SHOWING

CONCENTRATION VERSUS DEPTH. . . . . . . . . . . . . . . . A-l 
FIGURES

1 The Hanford Site. . . . . . . . . . . . . 2

2 Concentration History of Tritium in We11 699-40-1. . . . . 4

3 Wells Sampled for Contaminants in the Ground Water at Hanford . . . . . . . . . . . 6

4 Location of Wel1s 699-28-40, 699-31-31, and 699-37-43. . . . 10

5 Completion ScheduTes of Wells 699-28-40, 699-31-31, and 699-37-43.

6 Geologic Logs of Wel1s 699-28-40, 699-31-37, and 699-37-43.

7 Packer Assembly . . . . . . . . . . . . . . . 13

8 Present and Proposed Piezometer Locations (RHO) . . . . . 19

A.1 Concentration of Total Beta in We11 699-31-31 in 1975. . . A-3

A.2 Concentration of $60 \mathrm{CO}_{0}$ in We11 699-31-31 in 1975 . . . . A-4

A.3 Concentration of Tritium in Wel1 699-37-31 in 1975 . . . A-5

A.4 Concentration of 106Ru in we17 599-31-31 in 1975 . . . . A-6

A.5 Concentration of Total Beta in Ne11 699-31-31 in 1976. . . A-7

A.6 Concentration of $60 \mathrm{Co}$ in Wel1 699-31-31 in 1976 . . . . A-8

A.7 Concentration of Tritium in Well 599-31-31 in 1976. . . A-9

A.8 Concentration of $137 \mathrm{Cs}$ in Selected Wells in 1977. . . . A-10

A.9 Concentration of ${ }^{60} \mathrm{Co}$ in Selected Wells in 1977 . . . . A-11

A.10 Concentration of Tritium in Selected Wells in 1977 . . . A-12

A.11 Concentration of ${ }^{106} \mathrm{Ru}$ in Selected we11s in 1977. . . . A-13 


\section{TABLES}

1 Selected Contamination Results for Wells 699-28-40, 699-31-31, and 699-37-43, May 1975. . . . . . . . . 14

2 Phase I and Phase II Contamination Results for wel1 699-31-31. . 15

3 Phase III Contamination Results, July 1977 . . . . . . . 16 


\section{INTROCISCTION}

The Hanford Site is located in the south-central portion of Washington State near the city of Richland (Figure 1). The area was taken over by the U. S. Government in the 1940's'as a site to produce weapons-grade nuclear products. Nine production reactors were constructed on the site, of which only one is presently operating. In addition to the reactors, two chemical separations areas were constructed near the center of the site.

Activities on the site since 1944 have resulted in the disposal to the ground of large volumes of chemically and radioactively contaminated waste water. This water percolates laterally and downward through 50 to $100 \mathrm{~m}$ ( 150 to $300 \mathrm{ft}$ ) of unconsolidated sands, gravels, and silt until it eventually reaches the water table. Absorption and ion exchange reactions between the waterborne wastes and the earth materials effectively remove some of the longer lived and potentially more hazardous râdionuclides (2) (i.e., ${ }^{90} \mathrm{Sr},{ }^{137} \mathrm{Cs}$, and ${ }^{239} \mathrm{Pu}$ ).

Other radionuciides, such as ${ }^{106} \mathrm{Ru},{ }^{60} \mathrm{CO},{ }^{9} \mathrm{TC}$, and ${ }^{3} \mathrm{H}$, and nonradioactive constituents such as $\mathrm{NO}_{3}^{-}$have poor exchange characteristics and move through the ground at various rates until they enter the groundwater flow system. Once in the flow system they generally travel in a down-gradient direction. The concentrations of these constituents in the groundwater are reduced by radioactive decay, ion exchange, diffusion and hydrodynamic dispersion as they move through the flow system.

The disposal of large quantities of water in the separations areas $(34,000 \mathrm{lpm}$; up to 9,000 gpm), has resulted in groundwater mounds being superimposed on the natural flow system. (3) These mounds have increased the water-tabie gradient toward the river and have generated a potential for vertical gradients to form and drive contaminants to iower levels in the unconfined grouridwater fiow system. (4)

The work reported here was undertaken to ascertain whether or not the vertical components of flow beneath the groundwater mounds had resulted in contaminants being distributed vertically within the flow system, thereby presenting a path to the environment that was not being monitored. 


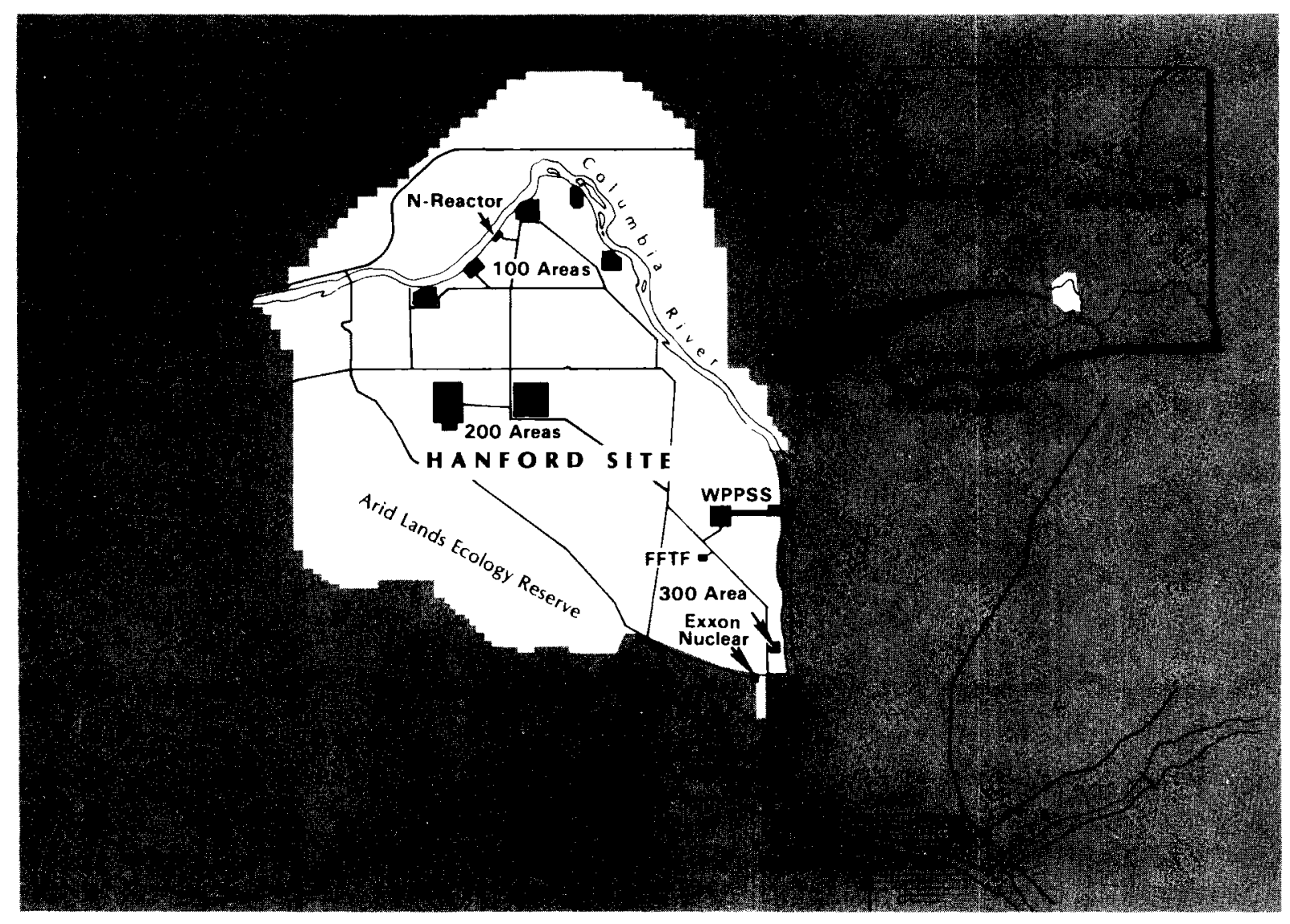

FIGURE 1. The Hanford Site 


\section{CONCLUSIONS AND RECOMMENDATIONS}

The present groundwater monitoring program, which samples the upper portions of the unconfined groundwater flow system, is appropriate because it samples that portion of an aquifer containing the most concentrated levels of contaminants. Hanford-originated contaminants do exist at trace levels at depths in the flow systems and should be sampled. However, because of the lower levels of contaminants, these deeper wells need not be sampled as frequently as the upper unconfined flow system.

Concentrations of contaminants are relatively higher near the surface of the unconfined flow system. The reasons for these higher concentrations are numerous and complex. The preferred path for the mounded water appears to be a radial flow pattern rather than a vertical flow.

An increase in potentiometric head with depth may be a factor in preventing the downward migration of contaminants being introduced at the mound locations. The effect of this upward movement of ground water should, theoretically, increase as the Columbia River is approached. This concept is supported by data from wel1 699-40-1.

A concentration history of Well 699-40-1 (Figure 2), shows a marked increase in tritium concentration following remedial work, which included the removal of a set of piezometers and the shortening of the water column. Upward vertical flow of uncontaminated ground water may have diluted the concentrations of contaminants, which may have caused the low readings obtained prior to rehabilitation work. 

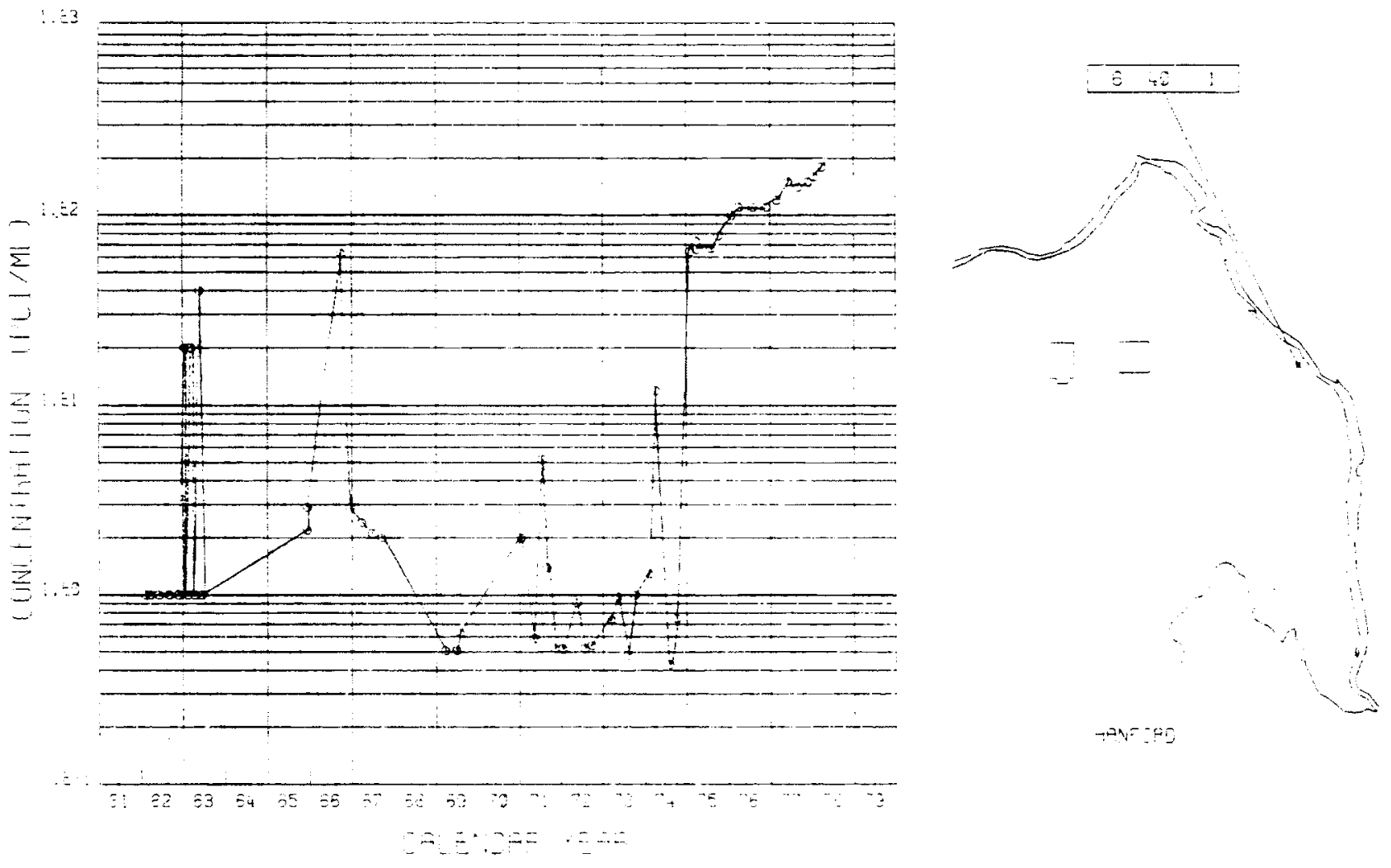

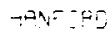

.

IIGURE 2. Concentration History of Tritium in Well 699-40-1 


\section{BACKGRPOUND}

Since 1944 , more than $5.3 \times 10^{11} \&\left(>14 \times 10^{10}\right.$ gal $)$ of process and cooling water containing low-level waste has been disposed to the ground near the separations areas. This disposal has had a significant effect on the water table. In addition, significant quartities of mobile chemical and radioactive contaminants have entered the water table and have been carried with the ground water in a down gradient direction toward the Columbia River. The Pacific Northwest Laboratory (PNL) carries out an extensive groundwater monitoring program to ascertain the dispersion and impact of these constituents on the environment.

\section{GROUNDWATER MONITORING PROGRAM}

The routine groundwater monitoring program is designed to assess the distribution and concentration of contaminants of Hanford origin in the ground water and to determine the impacts on man from the wastes transported via this pathway. To accomplish this, an extensive sampling and analysis effort is maintained. For example, in 1977 PNL conducted 2675 anaiyses from 939 samples obtained from 240 weils ${ }^{(3)}$ (Figure 3). (These analyses do not include anaiysis of the wells sampled for Rockwell Hanford Operations within the separations areas.) In addition, special sampling and analyses are made in response to unusual circumstances, i.e., unustia 1 analytical results and special requests from other contractors.

A program of well maintenance is conducted to ensure that quality groundwater sampling structures are preserved and that samples used in the program represent the groundwater flow system at a specific location. The monitoring program maintains a comprehensive data base, which supplies most of the groundwater data for the Hanford groundwater models. In addition, the program carries out supporting studies to aid in the definition of problem areas and to answer specific questions that are nct within the scope of the routine program.

The definition of the vertical distribution of contaminants within the Hanford groundwater ilow system is one of those special supporting 


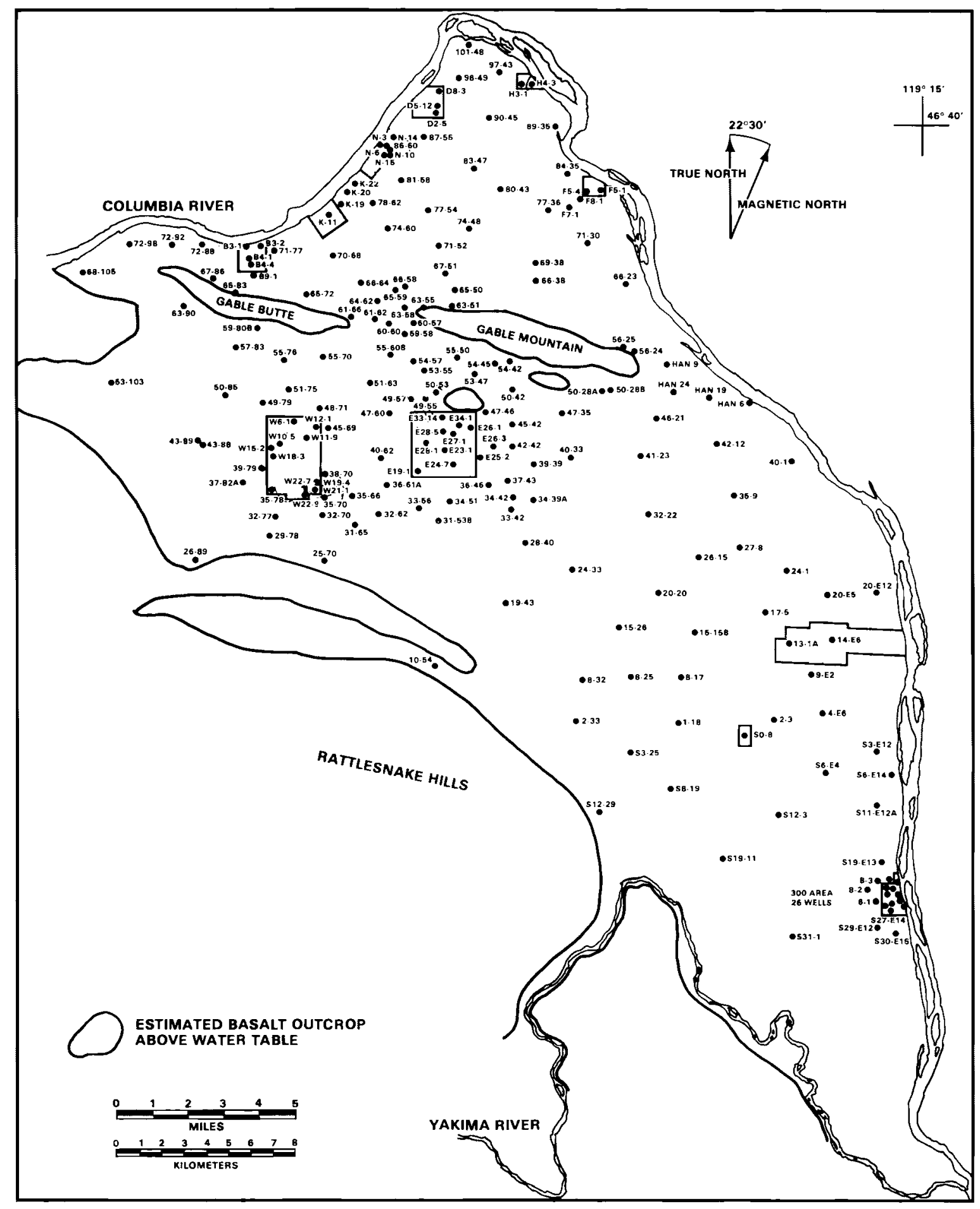

FIGURE 3. Wells Sampled for Contaminants in the Ground Water at Hanford 
studies. This study was carried out in three phases: Phase I started in 1975 and included analyses from three wells; Phase II used one well, with the analyses conducted by two laboratories; and Phase III was undertaken cooperatively with RHO and consisted of the installation of piezometers in selected wells and the testing of the piezometers. This type of testing was intended to determine if contaminants did in fact move vertically as well as horizontally.

\section{SAMPLING AND ANALYSIS}

The routine program currently collects samples from about 240 wells. Depending upon the location, the groundwater samples are analyzed for tritium, gross beta (as $106 \mathrm{Ru}$ ), the garma spectrum, and the nitrate ion. These analyses yield information on those contaminants most commonly found in the ground water. The samples are generally collected using submersible pumps installed in wells, tapping the upper 13 to $20 \mathrm{~m}$ (approximately 40 to $60 \mathrm{ft}$ ) of the unconfined aquiter.

\section{WELL MAINTENANCE PROGRAM}

In 1974, a program was begun to upgrade all of the wells used for groundwater monitoring on the Hanford Site. The wells available on the site had been drilled for a number of purposes, including monitoring, geological investigations, and hydrological irvestigations. The multipurpose nature of many of the wells and their different construction and completion methods resulted in a variety of structures that are not always compatible with good monitoring criteria.

In the early 1960s a program was begun to install piezometers at various depths within the aquifer system at Hanford. These piezometers were made of $1-1 / 2-i n$. ABS plastic pipe, with plastic well screens that were set opposite perforated zones in the we 11 casing and then isolated by backfilling with fine sand. (5) A high percentage of those installations failed because the plastic pipe collapsed when the wells were backfilled with sand or pumped for sampling. The structures proved to be inadequate for sampling because water did transfer through the fine sand, resuiting in cross-contamination. 
Starting in 1974 as part of the well maintenance program, these plastic piezometer tubes were removed and the wells were returned to their original specifications. Subsequent changes in water chemistry after rehabilitating the wells points out the need for eliminating the potential for transfer of contaminants from one portion of the aquifer to another and for removing the possibility of interaquifer transfer, which is a result of inadequately constructed wells. However, these wells, in their existing condition, could provide a means of determining the actual vertical distribution of contaminants within the Hanford groundwater flow system. 
METHODOLOGY

Several techniques were used in the past to determine if contaminants were reaching the lower levels of the unconfined aquifer system. These studies utilized deep samplers, which had special apparatuses to open sample containers at depth. Piezometers were installed at specific depths and isolated in individual large-diameter wells, and clusters of small-diameter wells were drilled to different depths. Only the individually drilled piezometers provided reproducible data.

\section{PHASE I}

The first phase was started in May 1975, with analyses completed in August 1975. This phase utilized three existing wells located in or near the known tritium and gross beta plumes. These wells were specifically constructed to allow sampling of the ground water at various depths below the surface of the water table. The locations of Wells 699-28-40, 699-31-31, and 699-37-43 are shown in Figure 4. The completion scheduies for the welis are shown in Figure 5. Figure 6 shows the geologic logs of the wells.

The zones sampled in this phase were isolated using a packer assembly similar to the system illustrated in Figure 7. This packer system originally used a small submersible pump between the inflatable packers; however, sanding problems forced the use of an "air-lift" sampling technique. A great deal of difficulty was experienced with this system because the packers were short-lived and had a stong tendency to leak. These leakages placed doubt on the validity of the testing.

This phase of the study pointed out that some contamination was present at depth in wel1 699-31-31, as shown by total $\beta$ at $94 \mathrm{mi}(270 \mathrm{ft}$ ) being $46 \mathrm{pCi} / 2$, versus $177 \mathrm{pCi} / 2$ at $184 \mathrm{~m}(530 \mathrm{ft})$. For details see Table 1 and the Appendix.

\section{PHASE II}

The second phase concentrated on Wel1 699-31-31, the only Phase I well that showed positive results. Phase II work essentialiy duplicated 


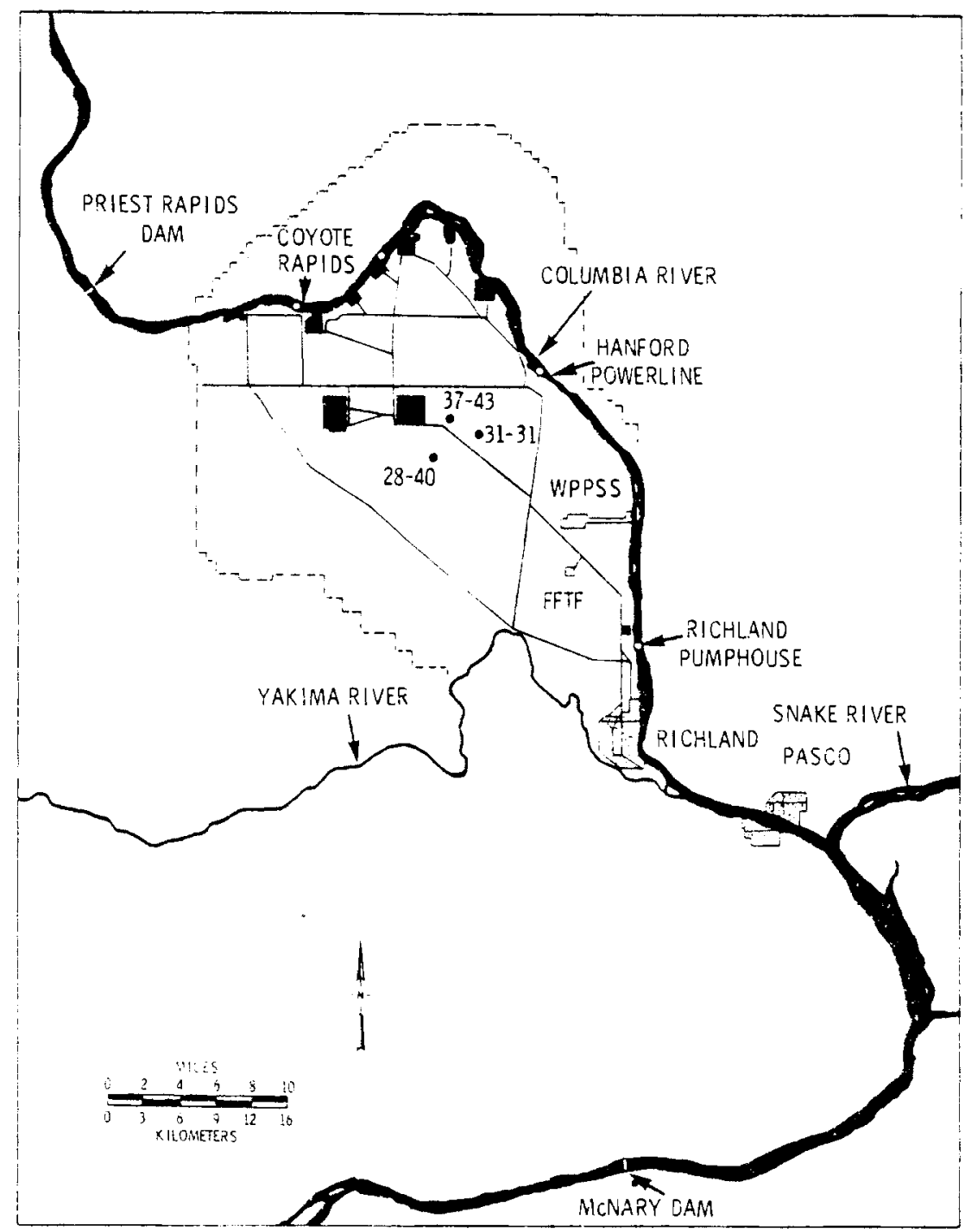

FIGURE 4. Location of We? $1 \mathrm{~s}$ 699-28-40, 699-31-31, and 699-37-43

Phase I, with the exception that replicate samples were analyzed for key contaminants by two different laboratories (PNL's Physical Sciences Department and the U.S. Testing Company). The we 11 cleanout and packer installation was contracted to a well drilling and testing company, which had wide experience and success with use of their packers in various wel? testing and operating activities. The isoiated zones were pumped at low rates to avoid excess stress on the well and aquifer, thereby avoiding possible bypass and cross contamination. 


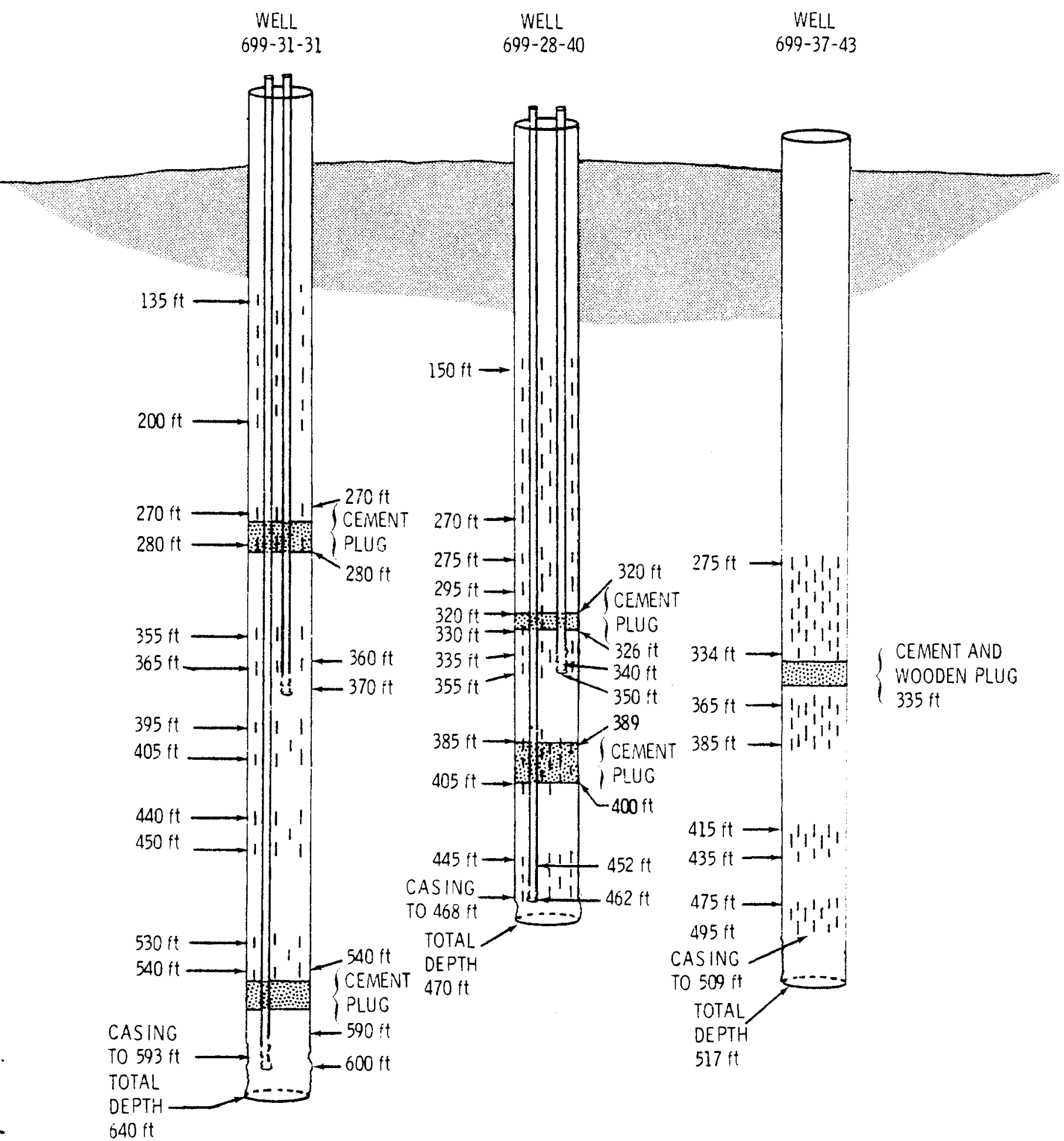

FIGURE 5. Completion Schedules of Well 699-31-31, 699-28-40, and 699-37-43 
SO RECORDS PRDBABLY SANO

${ }_{50}^{45} \longrightarrow$ COARSE SAND. LIRE SILT

- COARSE SANO

Th COARSE SAND, LITIE SHIT

$30 \square$ COARSE SAND

- No ReC ORD. probabi y CCARSE jant

30 - SANQ, LITLE SILT

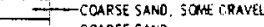

100 CoARSE SANO

10. NO RECORDS, PROBABLY COARSE SANO

III COARSE GRAVE,

1120 COARSE GRAVEL

18 GRAVEl. JOULERS

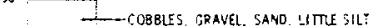

100

152 TrRAVEL añ̃ cCBales

157

155 COBBLES. JRAVEL, :ITIE SIET

+ iobirs gravel

— COBBLES SRAVE ANO SILT

$195-$ IMAL AND COARSE GRAVET.

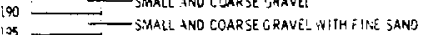

T) - TANO AND GRAVEL I TLE SIII

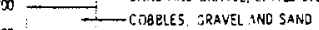

770 - CCBBLE5 GANAVL AND FINE SAND

$2150-$ SMALL AAlO COARSE CRAVIL ANO SAND

- 20 -Gravel, Sano LITIE SILt

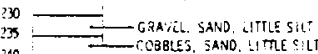

CPAMEL. SAND AN:C SILT

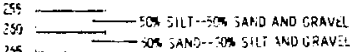

- SANO L!TIE SILS

20 - NORECOAO

ZTED SAND, LITLE GRSVE!

30

- cobble gravel ano san

$3:=$ BIUE CLAY

- URAYCAY

$337=$ = FINE GRAY SAND

SO URAY SAND ANO SHLT

SO - COARSE CRAVEL YERY LITTE SIL A AHO SAND

- COARSE gRavel a MID SANO

n?

- zlle clar. small grave

200

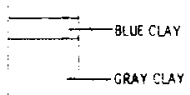

1373 TLUE CLAV ANO SMALL GRAVE

SI 7

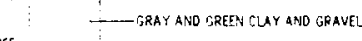

ISS Do CLAY AND EINE GRAY SINO

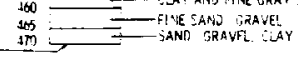

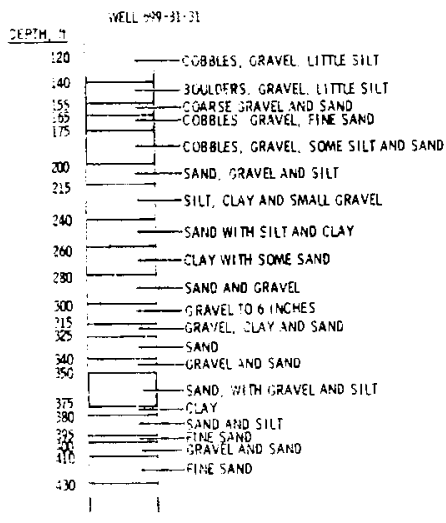

- CLAY

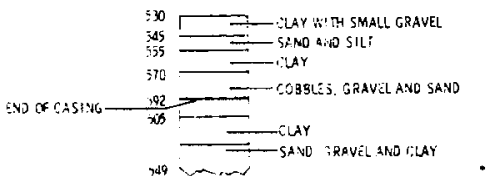

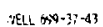

C. pqgDOMINATELY SANU

EPTH: :

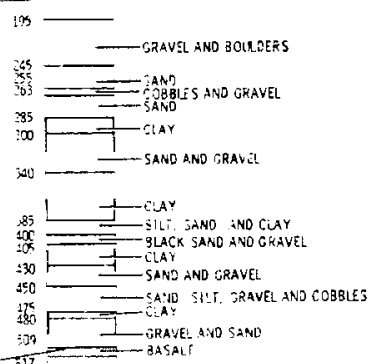

FIGURE 6. Geologic Logs of Wells 699-28-40, 699-31-31 and 699-37-43 


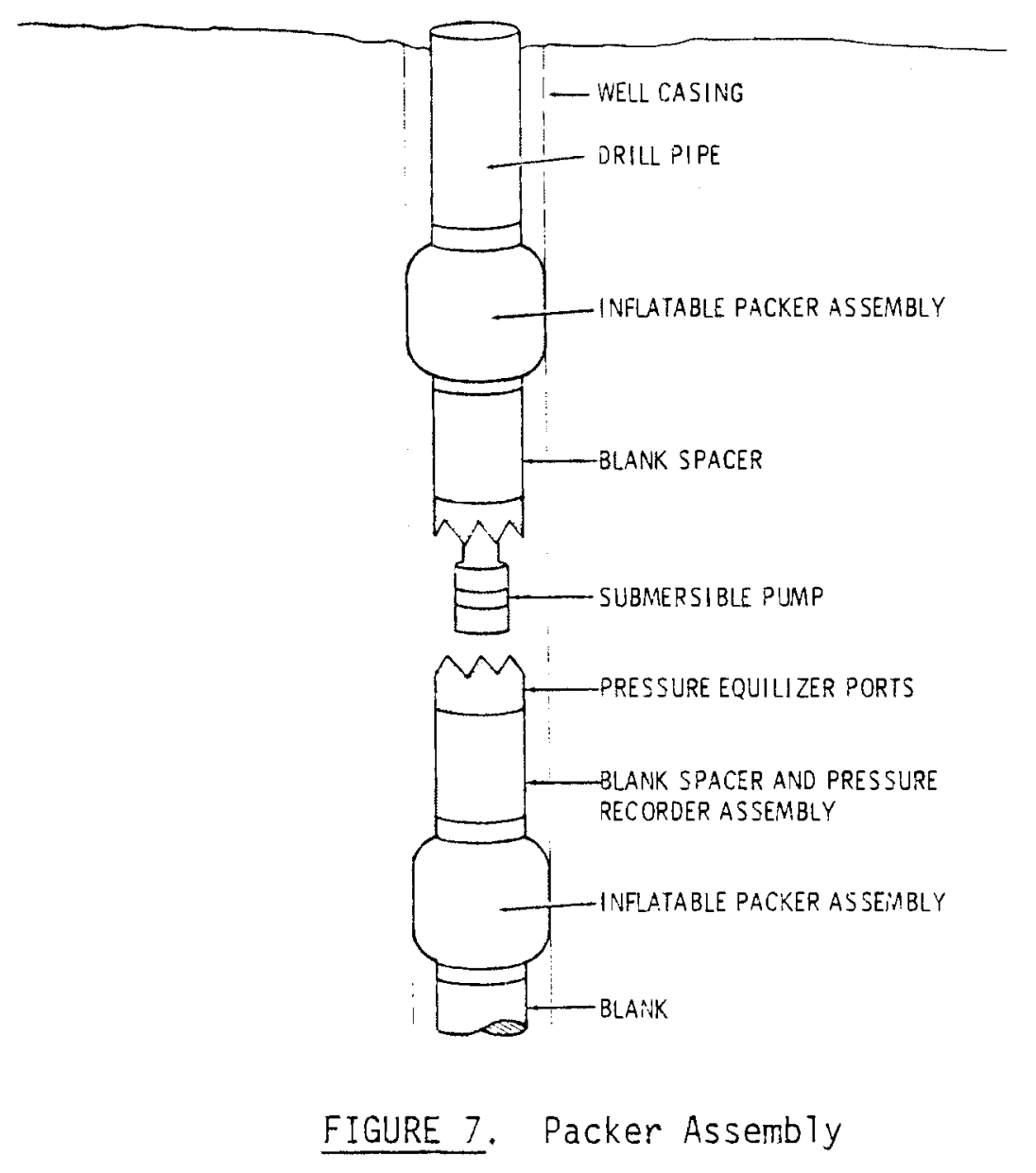

Phase II work started with the brushing, swabbing, and cleaning of Wel1 699-31-31. A downhole television system was used to examine the borehole, which showed that the brushing and swabbing were effective in removing scale and thus permitting a tight seal of the packer elements. The visual inspection showed that perforations listed as being at $108 \mathrm{~m}$ to $110 \mathrm{~m}$ ( $355 \mathrm{ft}$ to $360 \mathrm{ft}$ ) below the land surface ${ }^{(6)}$ were actually $108 \mathrm{~m}$ to $111 \mathrm{~m}$ (355 ft to $365 \mathrm{ft}$ ) below land surface. This second phase of the study was completed in June 1976, with sample analyses completed by August 1976.

Data from Phase II confirmed the data obtained from Phase I isee Table 2 and the Appendix). Contamination of the lower portion of the unconfined aquifer had occurred; however, concentrations of individual 
TABLE 1. Selected Contamination Results for Wells 699-28-40, 699-31-31, and 699-37-43, May 1975

\begin{tabular}{|c|c|c|c|c|c|}
\hline \multirow[b]{2}{*}{ We 11 No. } & \multirow[b]{2}{*}{ Depth, ft } & \multicolumn{4}{|c|}{ Constituents, $\mathrm{pCi} / \mathrm{l}$} \\
\hline & & $\begin{array}{c}\text { Total } \beta \text { as } \\
106 R u \\
\end{array}$ & ${ }^{3} \mathrm{H}$ & ${ }^{60} \mathrm{Co}$ & $\begin{array}{c}\text { Garma Scan } \\
106 \mathrm{Ru}\end{array}$ \\
\hline $\begin{array}{r}599-31-31 \\
28-40 \\
37-43\end{array}$ & $\begin{array}{l}270-284 \\
280-290 \\
287-301\end{array}$ & $\begin{aligned} 46 & \pm 15 \\
7.3 & \pm 4.5 \\
8 & \pm 5.7\end{aligned}$ & $\begin{array}{l}3.3 \times 10^{5} \\
<720 \\
1600 \pm 630\end{array}$ & $\begin{array}{c}55 \pm 26 \\
<41 \\
<87\end{array}$ & $\begin{array}{l}210 \neq 160 \\
<120 \\
<190\end{array}$ \\
\hline $\begin{array}{r}699-31-31 \\
28-40 \\
37-43\end{array}$ & $\begin{array}{l}350-364 \\
340-350 \\
365-383\end{array}$ & $\begin{aligned} & 32 \pm 15 \\
& 6.8 \pm 4.9 \pm 4.6 \\
& 7.4 \pm 5.6\end{aligned}$ & $\begin{array}{l}6.2 \times 10^{5} \\
<560 \\
<790\end{array}$ & $\begin{array}{c}69 \pm 27 \\
<48 \\
35 \pm 24\end{array}$ & $\begin{array}{l}170 \pm 160 \\
<210 \\
<120\end{array}$ \\
\hline $\begin{array}{r}699-31-31 \\
28-40 \\
37-43\end{array}$ & $\begin{array}{l}395-409 \\
400-410 \\
415-433\end{array}$ & $\begin{array}{c}14 \pm 14 \\
6.5 \pm 5 \\
7.3 \pm 4.9\end{array}$ & $\begin{array}{l}1.5 \times 10^{5} \\
<640 \\
<560\end{array}$ & $\begin{array}{c}37 \pm 25 \\
<37 \\
27 \pm 23\end{array}$ & $\begin{array}{l}160 \pm 160 \\
<110 \\
<150\end{array}$ \\
\hline $\begin{array}{r}699-31-31 \\
28-40 \\
37-43\end{array}$ & $\begin{array}{c}-- \\
450-460 \\
465-483\end{array}$ & $\begin{array}{c}=- \\
8.4 \pm 6 \\
5.8 \pm 5.7\end{array}$ & $\begin{array}{l}<-- \\
<640 \\
<710\end{array}$ & $\begin{array}{l}-- \\
<43 \\
<36\end{array}$ & $\begin{array}{l}<110 \\
<250\end{array}$ \\
\hline $699-31-31$ & $530-545$ & $177=27$ & $1.4 \times 10^{6}$ & $110 \pm 29$ & $160 \pm 140$ \\
\hline $699-31-31$ & 600 & \pm 19 & $6.5 \times 10^{5}$ & $58 \pm 26$ & -- \\
\hline
\end{tabular}

constituents appeared to be greater near the surface of the water table. Based on this knowledge and the criticism that complete isolation of a portion of an aquifer using inflatable packers is not assured, a broader based program was planned for Phase III of this study.

\section{PHASE III}

The third phase of this study was undertaken in cooperation with the Atlantic Richfield Hanford Company (ARHCO), which is now the Rockweil Hanford Operation (RHO). As part of an offsite migration program, several wells were selected by the ARHCO (RHO) staff for the installation of permanently installed piezometers. These piezometers were installed in existing wells after alterations were made to the wells to insure adequate verticai isolation (Figure 5). The wells were then sampled using air-lift techniques, so that an adequate sample volume could be obtained from the sma1l-diameter boreholes. An adequate sample volume was needed to assure that the samples were representative of the aquifer at that location. These samples were then analyzed for standard water quality 
TABLE 2. Phase I and Phase II Contamination Results for We11 699-31-31

\begin{tabular}{|c|c|c|c|c|c|c|c|}
\hline Date & Depth, ft & $\begin{array}{r}\text { Total } z \text { as } \\
10 \mathrm{Ru}, \mathrm{PCi} / \\
\end{array}$ & ${ }^{3} \mathrm{H}, \mathrm{pCi} / \mathrm{B}$ & $\begin{array}{l}60 \mathrm{Co} \\
0 \mathrm{Ci} / \mathrm{x}\end{array}$ & $\begin{array}{l}\text { Ca, } \\
\text { ppm }\end{array}$ & $\begin{array}{l}\mathrm{Na}, \\
\mathrm{ppm}\end{array}$ & $\begin{array}{l}\mathrm{NO}_{3}-\mathrm{N}, \\
\mathrm{ppm}\end{array}$ \\
\hline May 1975 & Water Surface & $193 \pm 25$ & $\times 10^{6}$ & $160 \pm 40$ & 47 & 34 & 15.4 \\
\hline June $1976^{(a)}$ & (at .150 ft) & 120 & $\times 10^{6}$ & $65 \pm 6$ & 47 & 32 & 13 \\
\hline June $1976^{(b)}$ & & $92 \pm 8$ & $1.8 \times 10^{6} \pm 17,000$ & -- & -- & - & 15 \\
\hline May 1975 & $270-280$ & $46 \pm 15$ & $3.3 \times 10^{5}$ & $55 \pm 26$ & 14.9 & 46.9 & 3.4 \\
\hline June $1976^{(a)}$ & & 110 & $1.6 \times 10^{6}$ & $43 \pm 5$ & 26 & 34 & 13 \\
\hline June $1976^{(b)}$ & & $67 \pm 7$ & $1.84 \times 10^{5}=8,300$ & & & & 16.5 \\
\hline May 1975 & $355-365$ & $32=13$ & $6.24 \times 10^{5}$ & $69 \pm 27$ & 21.5 & 44.5 & 6.5 \\
\hline June $1976^{(a)}$ & & 140 & $1.6 \times 10^{6}$ & $46 \pm 5$ & 22.5 & 34 & 11.5 \\
\hline June $1976^{(b)}$ & & $78 \pm 7$ & $1.92 \times 10^{6} \div 2.9 \times 10^{4}$ & & & & 17.5 \\
\hline May 1975 & $395-405$ & $14 \pm 10$ & $1.45 \times 10^{5}$ & $160 \pm 160$ & 9.8 & 49 & 0.67 \\
\hline June $1976^{(a)}$ & & 93 & $1.6 \times 10^{6}$ & $45 \pm 5$ & 21.5 & 34 & 0.35 \\
\hline June $1976^{(b)}$ & & $50 \pm 6$ & $1.44 \times 10^{6} \pm 1.3 \times 10^{4}$ & & & & 16.5 \\
\hline May 1975 & $535-545$ & $64=26$ & $3.71 \times 10^{5}$ & $62 \pm 26$ & 15.8 & 51.6 & -- \\
\hline June $1976^{(a)}$ & & $<75$ & $4.3 \times 10^{5}$ & $5.2=5.6$ & 18.2 & 50 & 3.5 \\
\hline June $1976^{(b)}$ & & $3 \hat{3}=6$ & $4.58 \times 10^{5}=1.4 \times 10^{4}$ & & & & 4.5 \\
\hline May 1975 & Below 575 & $72=12$ & $6.59 \times 10^{5}$ & $110 \pm 29$ & 21.5 & 40.9 & 6.7 \\
\hline June $1976^{(a)}$ & & $<75$ & $9.9 \times 10^{5}$ & $35=6$ & 30 & 46.5 & 9.0 \\
\hline June $1976^{(b)}$ & & $53 \pm 7$ & $9.44 \times 10^{5} \div 1.2 \times 10^{4}$ & & & & 9.5 \\
\hline
\end{tabular}

(a) Analysis by PNL's Radiological Sciences Department.

(b) Analysis by U. S. Testing Company.

parameters plus selected radionuclides. The wells showed some contamination with depth; however, the vast majority of contaminants were found to be in the upper portions of the aquifer system. Data obtained during Phase III are contained in Table 3.

Rockwell Hanford Operations (RHO) Work

For several years $\mathrm{RHO}$ researchers have studied the flow of contaminants into the ground water and the resulting stratification of the waste. Several unpublished reports were generated, which have very 1 imited distribution. $(7,8,9,10)$ The information and data appear to have been either lost in old files or destroyed. Therefore, in 1976 an intense 
TABLE 3. Fhase III Contamination Results, July 1977

\begin{tabular}{|c|c|c|c|c|c|c|c|c|}
\hline & $\mathrm{pH}$ & $\begin{array}{c}\text { Conductivity, } \\
\text { umohs } / \mathrm{cm}\end{array}$ & $\begin{array}{l}\mathrm{HCO}_{3}, \\
\mathrm{mg} / 2\end{array}$ & $\begin{array}{l}C O_{2} \\
\mathrm{mg} / \hat{\mathrm{C}}\end{array}$ & $\begin{array}{r}\mathrm{Cl}, \\
\mathrm{mg} / \ell \\
\end{array}$ & $\begin{array}{l}\mathrm{SO}_{4}-S, \\
\mathrm{mg} / \ell\end{array}$ & $\begin{array}{l}\mathrm{NO}_{3}-\mathrm{N}, \\
\mathrm{mg} / \mathrm{l}\end{array}$ & $\begin{array}{c}\text { Dissolved } \\
\text { Solids } \\
\mathrm{mg} / \ell\end{array}$ \\
\hline \multicolumn{9}{|l|}{ We11 $699-10-E-12$} \\
\hline $74 \mathrm{ft}$ (Surface) & 7.5 & 250 & 120 & 0 & 5.7 & 8 & 3.8 & 243.0 \\
\hline $360 \mathrm{ft}$ & 7.9 & 350 & 188 & 0 & 14.2 & 1 & 0.05 & 361 \\
\hline \multicolumn{9}{|l|}{ well 699-14-38 } \\
\hline $112 \mathrm{ft}$ (Surface) & 8.05 & 300 & 132 & 0 & 3.5 & 9.0 & 0.2 & 229 \\
\hline $178 \mathrm{ft}$ & 8.1 & 290 & 134 & 0 & 3.0 & 8.5 & 0.3 & 250 \\
\hline $380 \mathrm{ft}$ & 7.95 & 250 & 135 & 0 & 3.5 & 8.5 & 0.5 & 280.0 \\
\hline \multicolumn{9}{|l|}{ Well $699-28-40$} \\
\hline $157 \mathrm{ft}$ (Surface) & 7.75 & 350 & 133 & 0 & 7.5 & 18.5 & 3.1 & 311.0 \\
\hline $340 \mathrm{ft}$ & 7.9 & 250 & 139 & 0 & 1.5 & 8 & $<0.05$ & 208.0 \\
\hline $468 \mathrm{ft}$ & 7.75 & 220 & 106 & 0 & 3.5 & 8 & 0.05 & 177 \\
\hline \multicolumn{9}{|l|}{ We11 699-31-31 } \\
\hline $128 \mathrm{ft}$ (Surface) & 7.5 & 500 & 110 & 0 & 10.7 & 19.5 & 14.4 & 370 \\
\hline $360 \mathrm{ft}$ & 7.7 & 300 & 127 & 0 & 9.5 & 25 & $<0.05$ & 348 \\
\hline $590 \mathrm{f}:$ & 8.0 & 250 & 152 & 0 & 3.5 & 1 & $<0.05$ & 247 \\
\hline \multicolumn{9}{|l|}{ Well 699-32-72 } \\
\hline 209 it (Surface) & 7.9 & 350 & 88 & 14.44 & 43.4 & 8.5 & 4.5 & 210 \\
\hline $465 \mathrm{ft}$ & 7.3 & 400 & 144 & 0 & 18.5 & 10.5 & 0.1 & 202 \\
\hline \multicolumn{9}{|l|}{ Well $699-38-65$} \\
\hline $322 \mathrm{ft}$ (Surface) & 7.5 & $4 \approx 0$ & 133 & 0 & 9.7 & 12 & 13.6 & 396 \\
\hline $460 \mathrm{ft}$ & 3.0 & 350 & 153 & 0 & 4.5 & 7.5 & 0.4 & 262 \\
\hline \multicolumn{9}{|l|}{ 'vell 599-50-42 } \\
\hline $59 \mathrm{ft}$ (Surface) & 3.6 & 500 & 0 & 28.9 & 35.5 & 75 & 0.4 & 377 \\
\hline $110 \mathrm{ft}$ & 7.7 & 350 & $i 12$ & 0 & 28.4 & 10 & 0.75 & 197 \\
\hline \multicolumn{9}{|l|}{ Well 699-51-75 } \\
\hline $192 \mathrm{ft}$ (Surface) & 8.1 & 400 & 97 & 18 & 15.6 & 14.5 & 4.4 & 220 \\
\hline $370 \mathrm{ft}$ & 8.0 & 350 & 139 & 0 & 10.7 & 11 & 0.2 & 212 \\
\hline \multicolumn{9}{|l|}{ Well 699-53-55A } \\
\hline $174 \mathrm{ft}$ (Surface) & 7.9 & 200 & 83 & 0 & 25.5 & 8.5 & $<0.05$ & 278 \\
\hline $330 \mathrm{ft}$ & 8.0 & 450 & 96 & 0 & 25.7 & $j .5$ & 0.2 & 300 \\
\hline \multicolumn{9}{|l|}{ Well 699-67-51 } \\
\hline $124 \mathrm{ft}$ (Surface) & 7.7 & 480 & 128 & 0 & 13.5 & 5.5 & 0.3 & 170 \\
\hline $184 \mathrm{ft}$ & 11.3 & 350 & 0 & 72 & 8.0 & 23.5 & 0.05 & 1119 \\
\hline \multicolumn{9}{|l|}{ Well o99-96-49 } \\
\hline $36 \mathrm{ft}$ (Surface) & 7.6 & 400 & 92 & 3 & 32 & 19.5 & 1.7 & 238 \\
\hline $79 \mathrm{ft}$ & 7.5 & 350 & 87 & 0 & 27 & 14.5 & 0.5 & 203 \\
\hline \multicolumn{9}{|l|}{ well 699-\$12-29 } \\
\hline $84 \mathrm{ft}$ (Surface) & 7.9 & 400 & 74 & 0 & 9.2 & 14.5 & 3.6 & 281 \\
\hline $147 \mathrm{ft}$ & 7.6 & 350 & 72 & 0 & 12 & 16 & 0.1 & 252 \\
\hline $180 \mathrm{ft}$ & 8.1 & 500 & 124 & 0 & 23.5 & 9.5 & 0.3 & 308 \\
\hline
\end{tabular}

ND - iot Detected.

*Large error percentage noted - the nuclide may not be present. 
TABLE 3. (Continued)

\begin{tabular}{|c|c|c|c|c|c|c|c|c|c|}
\hline $\begin{array}{c}3 \\
\mathrm{mg} / \mathrm{\ell} \\
\end{array}$ & $\begin{array}{c}\mathrm{Ca} \\
\mathrm{mg} / \mathrm{z}\end{array}$ & $\begin{array}{c}\mathrm{Mg} \\
\mathrm{mg} / \mathrm{Z} \\
\end{array}$ & $\begin{array}{r}k \\
m g / 2 \\
\end{array}$ & $\begin{array}{c}\mathrm{Na} \\
\mathrm{mg} / \mathrm{l}\end{array}$ & $\begin{array}{l}60 \mathrm{Co} \\
\mathrm{pCi} / \mathrm{\ell} \\
\end{array}$ & $\begin{array}{l}105 \mathrm{Ru} \\
\mathrm{pCi} / 2 \\
\end{array}$ & $\begin{array}{l}134 \mathrm{Cs} \\
\mathrm{OCi} / 2 \\
\end{array}$ & $\begin{array}{l}137 \mathrm{Cs} \\
\mathrm{pCi} / 2 \\
\end{array}$ & $\begin{array}{c}3 \mathrm{H} \\
\mathrm{pCi} / 2 \\
\end{array}$ \\
\hline$<0.05$ & 22 & 6.8 & 7.1 & 20.5 & .05 & ND & ND & ND & \\
\hline 0.06 & 12 & 3.7 & 8.6 & 55.0 & .016 & ND & ND & ND & \\
\hline$<0.05$ & 25 & 9.2 & 6.5 & 11.5 & .011 & ND & ND & .023 & \\
\hline$<0.05$ & 26.5 & 7.5 & 44 & 11.5 & .025 & ND & ND & NO & \\
\hline$<0.05$ & 34.5 & 46.5 & 49.5 & 22.5 & .17 & ND & ND & ND & \\
\hline ; & & & & & & & & & \\
\hline$<0.05$ & 23.5 & 9.2 & 5.8 & 17.5 & 1.5 & .03 & ND & ND & $3.7 \times 10^{5}$ \\
\hline$<0.05$ & 18.5 & 7.0 & 4.6 & 12.5 & .011 & ND & ND & NO & \\
\hline$<0.05$ & 9.5 & 2.0 & 2.6 & 24 & .05 & ND & ND & ND & \\
\hline 0.05 & 26.5 & 10.5 & 8.0 & 12.0 & 52 & 13 & .045 & ND & $3.8 \times 10^{5}$ \\
\hline$<0.05$ & 19 & 3.5 & 6.5 & 28 & 11 & 1.4 & ND & ND & $3.0 \times 10^{5}$ \\
\hline 0.06 & 5 & 1.0 & 5.8 & 42 & .032 & ND & ND & ND & \\
\hline 0.15 & 32 & 3.4 & 4.0 & 12 & .0051 & .014 & ND & .019 & $1.3 \times 10^{7}$ \\
\hline$<0.05$ & 35 & $i 3$ & 4.5 & 14 & iND & NO & ND & ND & $9.8 \times 10^{5}$ \\
\hline$<0.5$ & 34.5 & 17.7 & 5.7 & 16 & .19 & .017 & iND & NO & $2.7 \times 10^{6}$ \\
\hline$<0.5$ & 26.5 & $\vdots 1.6$ & 5.3 & 14 & .0051 & ND & $M D$ & NO & \\
\hline$<0.05$ & 41 & 2.2 & 8 & 18 & .028 & $\because 10$ & ND & ND & \\
\hline$<0.05$ & 12 & 9 & 4.5 & 15 & .021 & ND & ND & .025 & \\
\hline$<0.05$ & 35 & 12 & 4 & 8 & .0030 & ND & $N D$ & .050 & \\
\hline$<0.05$ & 35 & 8.4 & 5 & 12 & .0035 & NO & No & NO & \\
\hline 2.55 & 37 & 12.5 & 8.5 & 12.5 & ND & ND & $.0039 *$ & ND & \\
\hline 0.2 & 37 & 13 & 8.5 & 13.0 & ND & .023 & ND & No & \\
\hline 0.25 & 125 & 6.8 & 5 & 16 & .10 & .037 & ND & .015 & \\
\hline 0.7 & 340 & $<0.1$ & 18 & 31 & .024 & $.019 *$ & ND & ND & $9.8 \times 10^{4}$ \\
\hline $0 . i$ & 21 & 7.2 & 4.5 & 11 & .026 & ND & ND & .016 & $1.8 \times 10^{6}$ \\
\hline$<0.05$ & 17 & 6.4 & 5 & 6.5 & .012 & No & ND & ND & $6.5 \times 10^{5}$ \\
\hline 0.1 & 37 & 8 & 6 & 13.5 & .024 & ND & ND & $.013^{\star}$ & \\
\hline 0.1 & 27 & 3 & 8 & 15 & .0017 & .022 & ND & .13 & \\
\hline 0.1 & 47.5 & 14 & 8 & 14 & .0080 & ND & ND & .030 & \\
\hline
\end{tabular}


program was started in cooperation with PNL to estabiish a network of piezometers. The work involved the installation of piezometers at selected well sites within the Hanford Site. Twenty-eight well sites were selected for rehabilitation, piezometer installation, and hydraulic testing during FY-1977. During FY-1978 an additionai 12 welis are scheduled to be rehabilitated, have piezometers installed and be hydraulically tested (Figure 8). The final series, scheduled for FY-1979, will complete the rehabilitation, installation of piezometers and hydraulic testing of any remaining wells.

\section{Study Description}

The assessment of data for iong-term prediction of potential contaminant migration in the ground water involves the identification of the characteristics that are pertinent to evaluating the subsurface system of fluid flow and contaminant transport. The objective of the study was to establish a piezometric network that would be able to differentiate and assess the boundary between artificial recharge at Hanford and the natural groundwater flow systems.

The most promising and potentially usefu? computer codes and models identified in FY-1976 were adapted to the specific predictive needs of the Hanford Site, and their accuracy was tested against actual groundwater flow and contaminant data. (1i) With model availability firmiy established and their predictive capability strengthened, the models can be used to predict groundwater and contaminant movement resulting from future Hanford operations and/or local agricultural developments. These detailed impact studies would allow for the proper hydrologic management of the Hanford groundwater flow systems, which would minimize any doubts as to the present or future consequences of radiological contamination underlying the Hanford Site. By recognizing all data requirements and having the most suitable computer systems available to handle this information, maximum credibi? ity would be achieved in the use of predictive modeling results.

Planning for the long-term groundwater management program and evaluating the computer codes and data base available for groundwater 


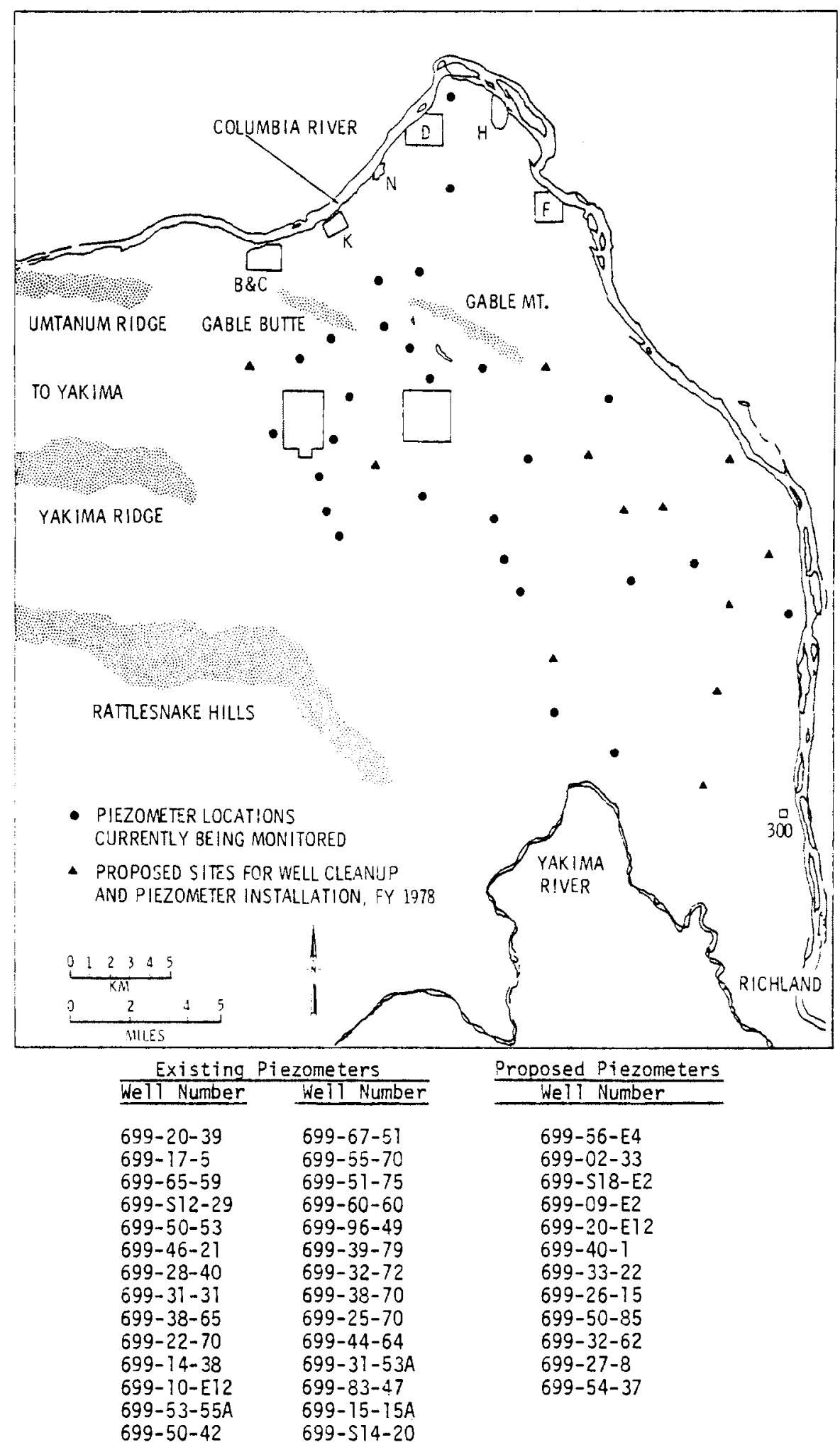

FIGURE 8. Present and Proposed Piezometer Locations (RHO) 
management of high-level waste areas was completed in FY-1976. Model development, testing and adaption, and data base improvements will continue until 1981. Hydrological studies of high-level waste areas and the definition of impacts of onsite and offsite activities on wastemanagement programs will continue through FY-1982 if funding is available. 


\section{REFERENCES}

1. U. S. Energy Research and Development Administration, "Waste Manage Operations," Final Environmental Statement. ERDA-1538, Rich1and, WA 99352.

2. D. J. Brown, Migration Characteristics of Radionuclides Through Sediments Underlying the Hanford Reservation. ISO-SA-32, Rockwel1 Hanford Operations, Richland, WA 99352, 1967.

3. D. A. Myers, Environmental Monitoring Report on the Status of Groundwater Beneath the Hanford Site January-December 1977. PNL-2624, Batte11e, Pacific Northwest Laboratories, Richland, WA 99352, Apri1 1978.

4. P. A. Eddy, R. E. Gephart, R. C. Arnett and G. A. Robinson, Geohydrologic Study of the West Lake Basin. ARH-CD-775, Atlantic Richfield Hanford Company, Richland, WA 99352, October 1976.

5. D. J. Brown, "Piezometeric Head Distribution in Sand Filled Wells." Journal of Hydrology $i: 195-203,1963$.

6. V. L. McGhan and D.W. Damschen, Hanford Wells. BNWL-2296, Battelle, Pacific Northwest Labcratories, Richland, WA 99352, June 1977.

7. Members of Chemical Effiuents Technology Operation, Chemical Effluents Technology Waste Disposal Investigations, July, August, September, 1956. ed. by D. J. Brown, HW -49465 , DOE Technical Information Center, Oak Ridge, TN, April 12, 1957.

8. Members of Chemical Effluents Technology Operation, Chemical Effluents Technology Waste Disposal Investigations, January, February, March, 1957. ed. by D. J. Brown, HW - 51095, DOE Technical Information Center, Oak Ridge, TN, June 26, 1957.

9. Members of Chemical Effluents Technology Operation, Chemical Effluents Technology Waste Disposal Investigations, July, Auqust, September, 1957. ed. by D. U. Brown, HW -54555 , DOE Technical Information Center, Dak Ridge, TN, December 27, 1957.

10. Members of Chemical Effluents Technology Operation, Chemical Effluents Technology Waste Disposal Investigations, July, August, September, 1960. ed. by W. A. Haney, HW - 67753 - RD, National Technical Information Service, 5285 Port Royal Road, Springfield, VA 22161, 1960.

11. K. L. Kipp, A. E. Reisenauer, C. R. Cole and C. A. Bryan, Variable Thickness Transient Groundwater Flow Model Theory and Numerical Implementation. BNWL-1703, Battelle, Pacific Northwest Laboratories, updated 1976. 


\section{ACKNOWLEDGEMENTS}

Acknowledgement is made of the cooperation and funding of the U. S. Department of Energy. V. L. McGian, R. W. Wallace, and E. L. Hilty, of PNL, and R. W. Bryce from RHO provided assistance in obtaining, compiling, and analyzing the data. L. R. Jaech edited and arranged for publication and P. A. Purvis typed the manuscript. 


\section{APPENDIX}

GRAPHS OF SELECTED WELLS SHOWING CONCENTRATION VERSUS DEPTH 


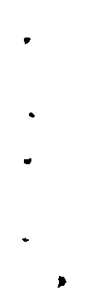

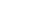

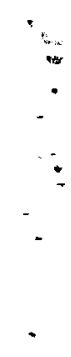

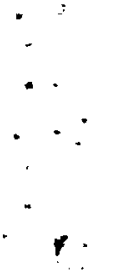

. 


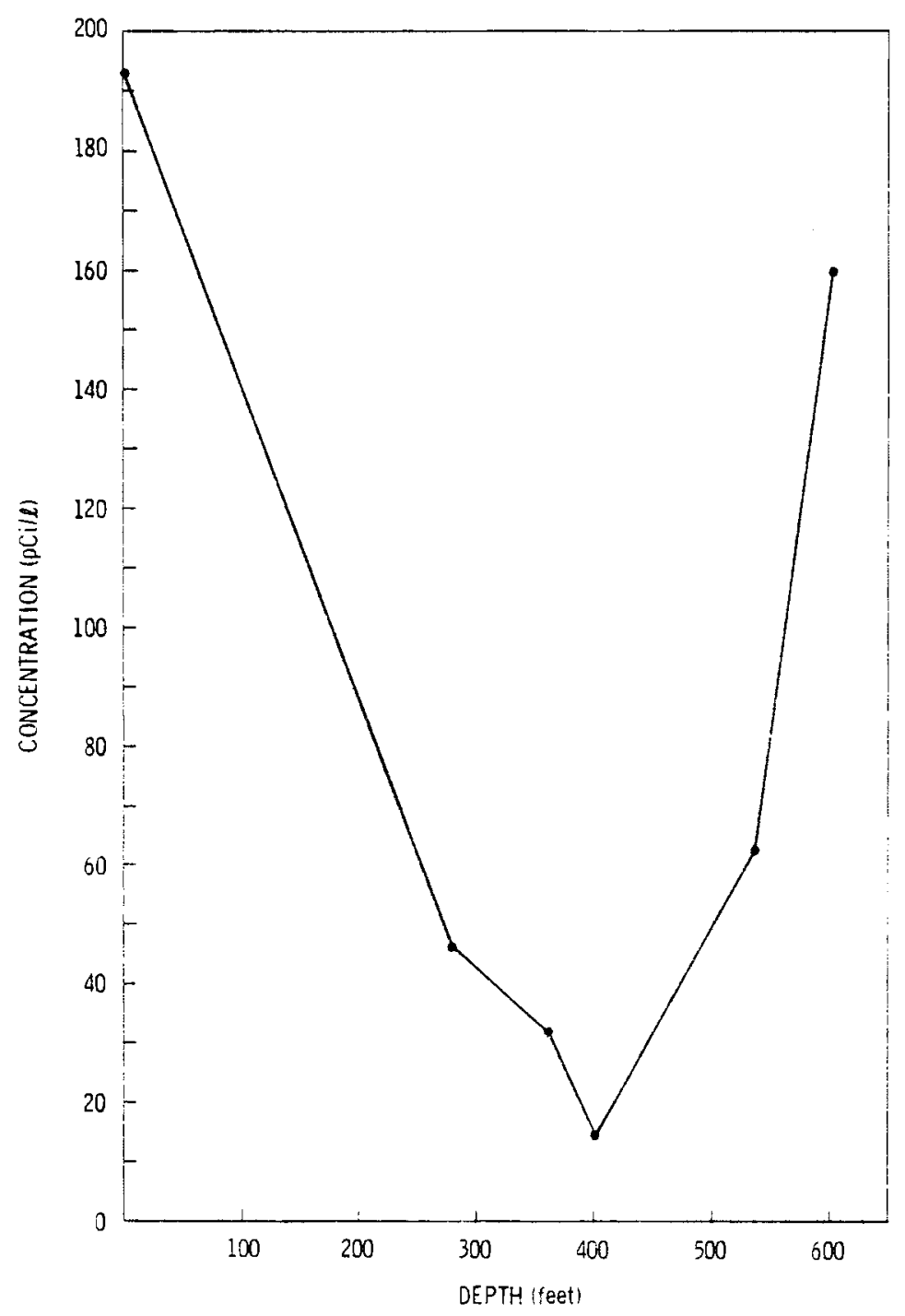

FIGURE A.1. Concentration of Total Beta in We11 699-31-31 in 1975 


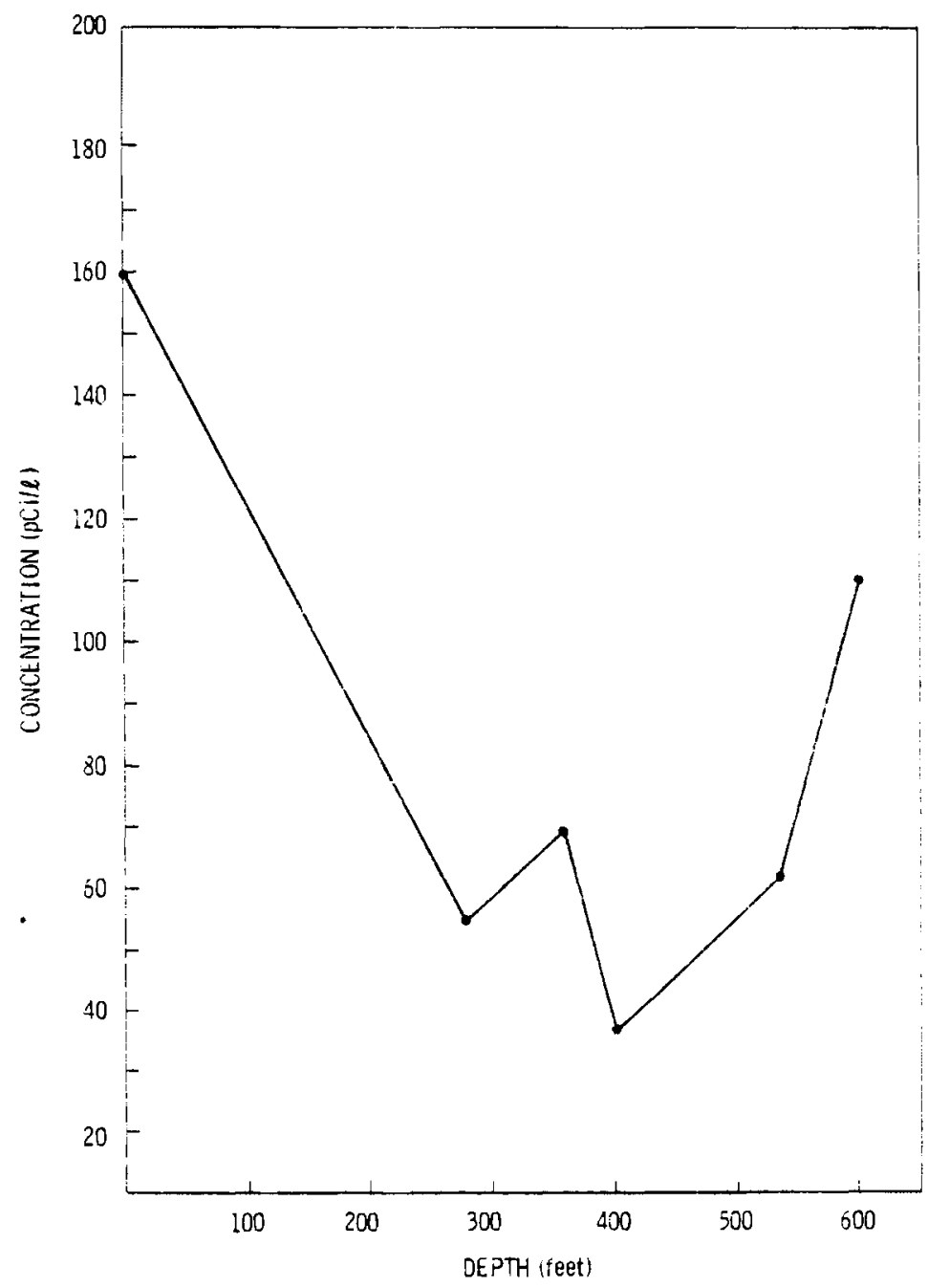

FIGURE A.2. Concentration of $60 \mathrm{Co}$ in well 699-31-31 in 1975 


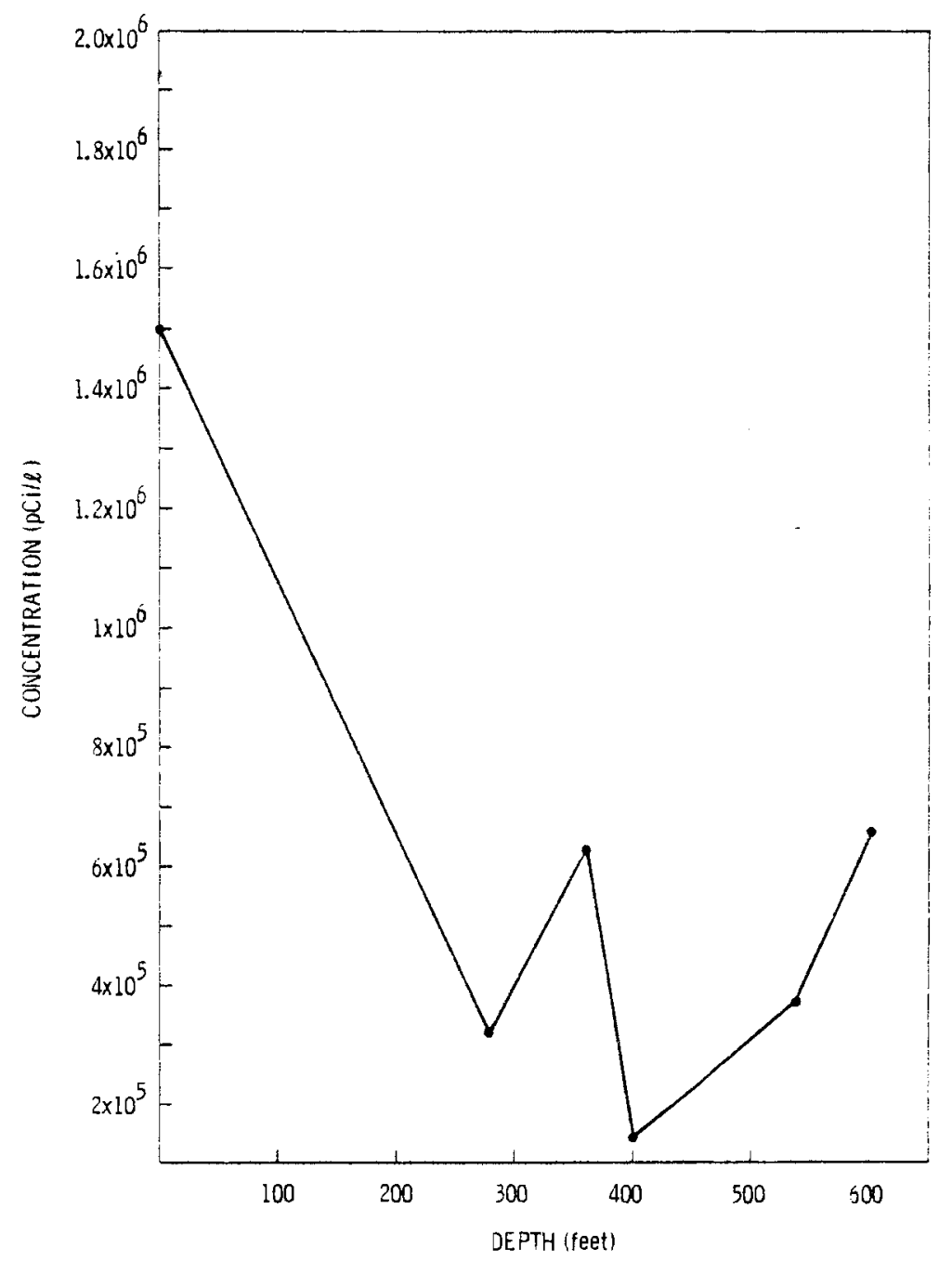

FIGURE A.3. Concentration of Tritium in well 699-31-31 in 1975 


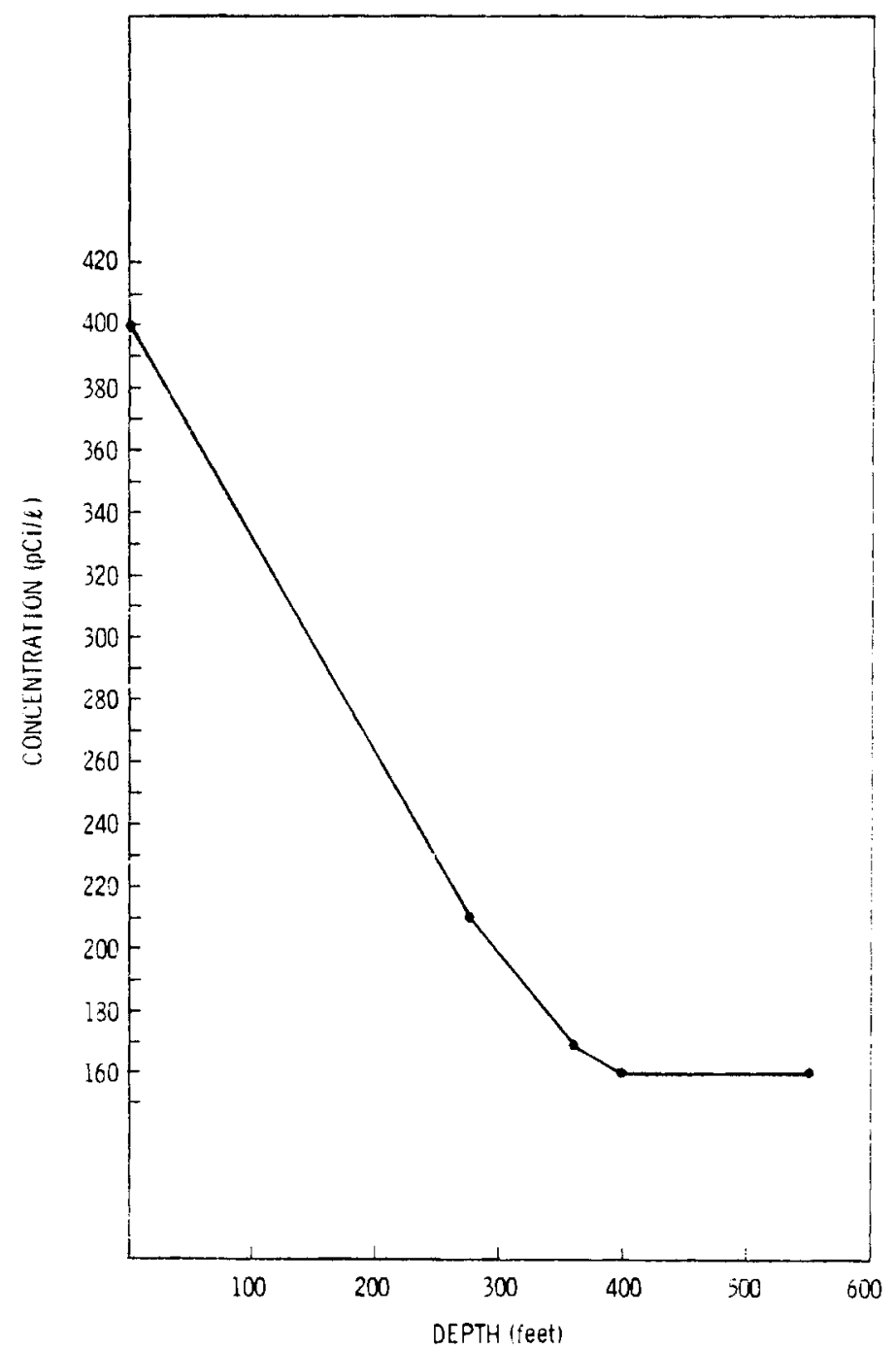

FIGURE A.4. Concentration of 105 Ru in Well 699-37-31 in 1975 


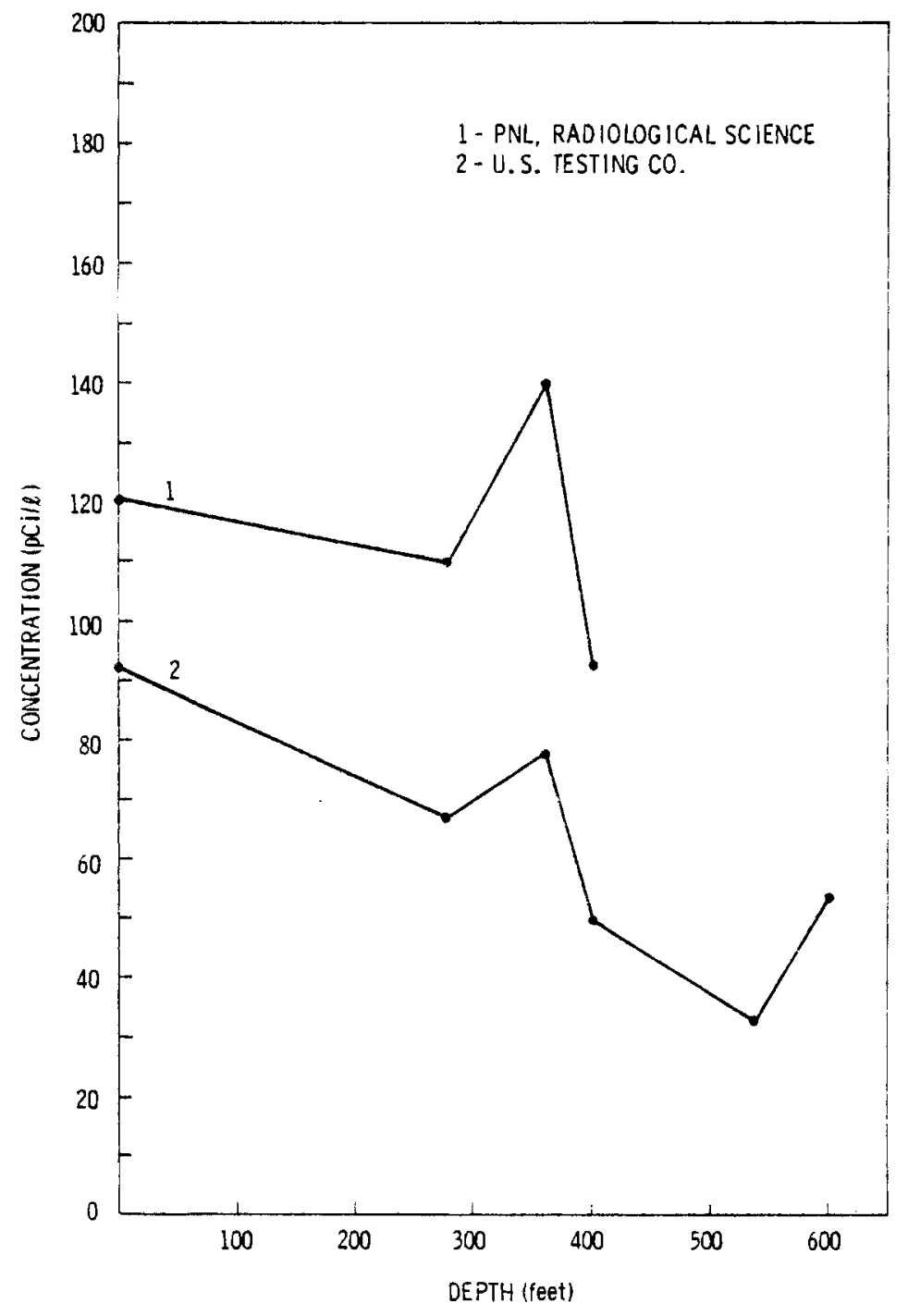

FIGURE A.5. Concentration of Total Beta in We11 699-31-31 in 1976 


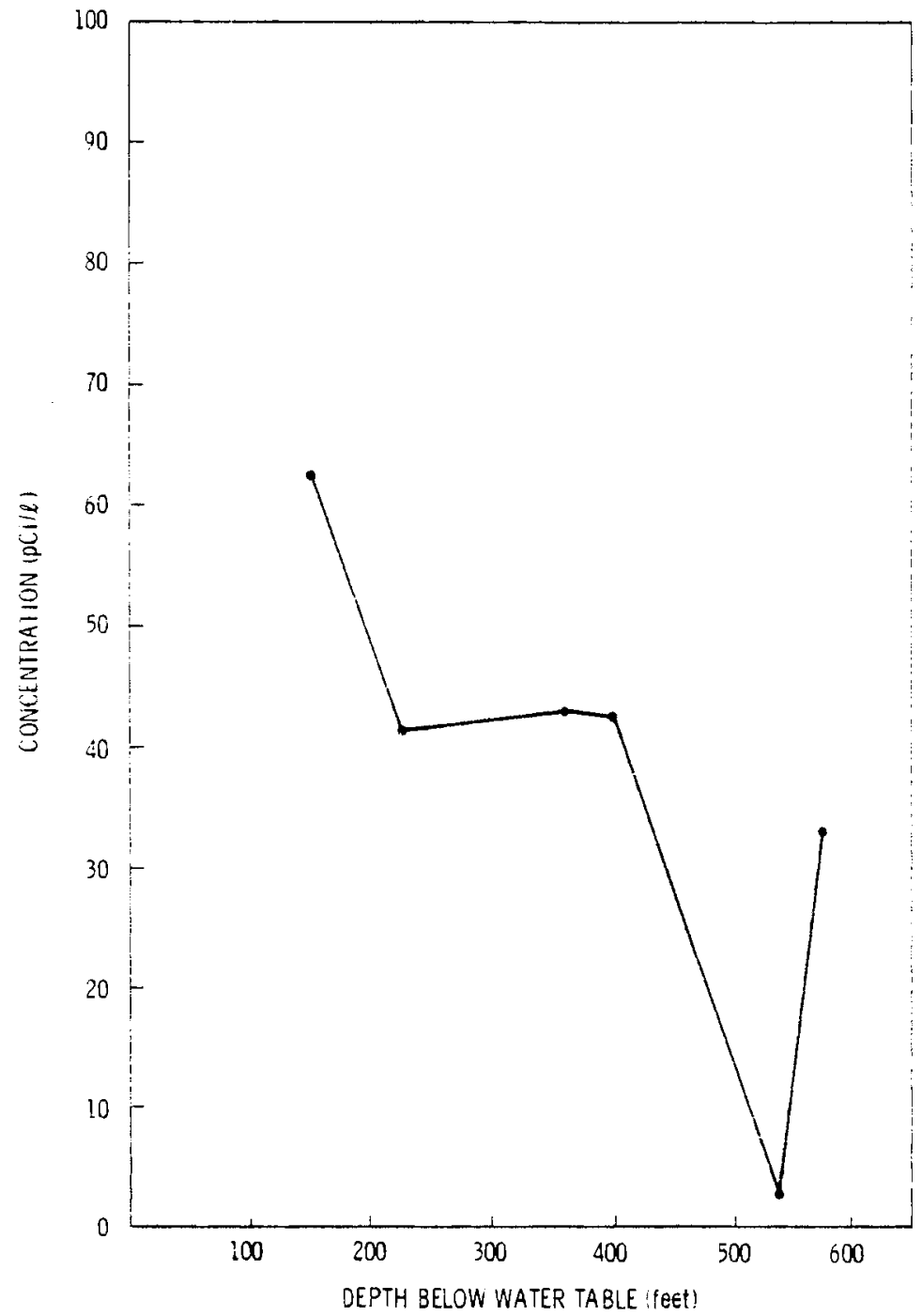

FIGURE A.6. Concentration of $60 \mathrm{CO}$ in well 699-31-31 in 1976 


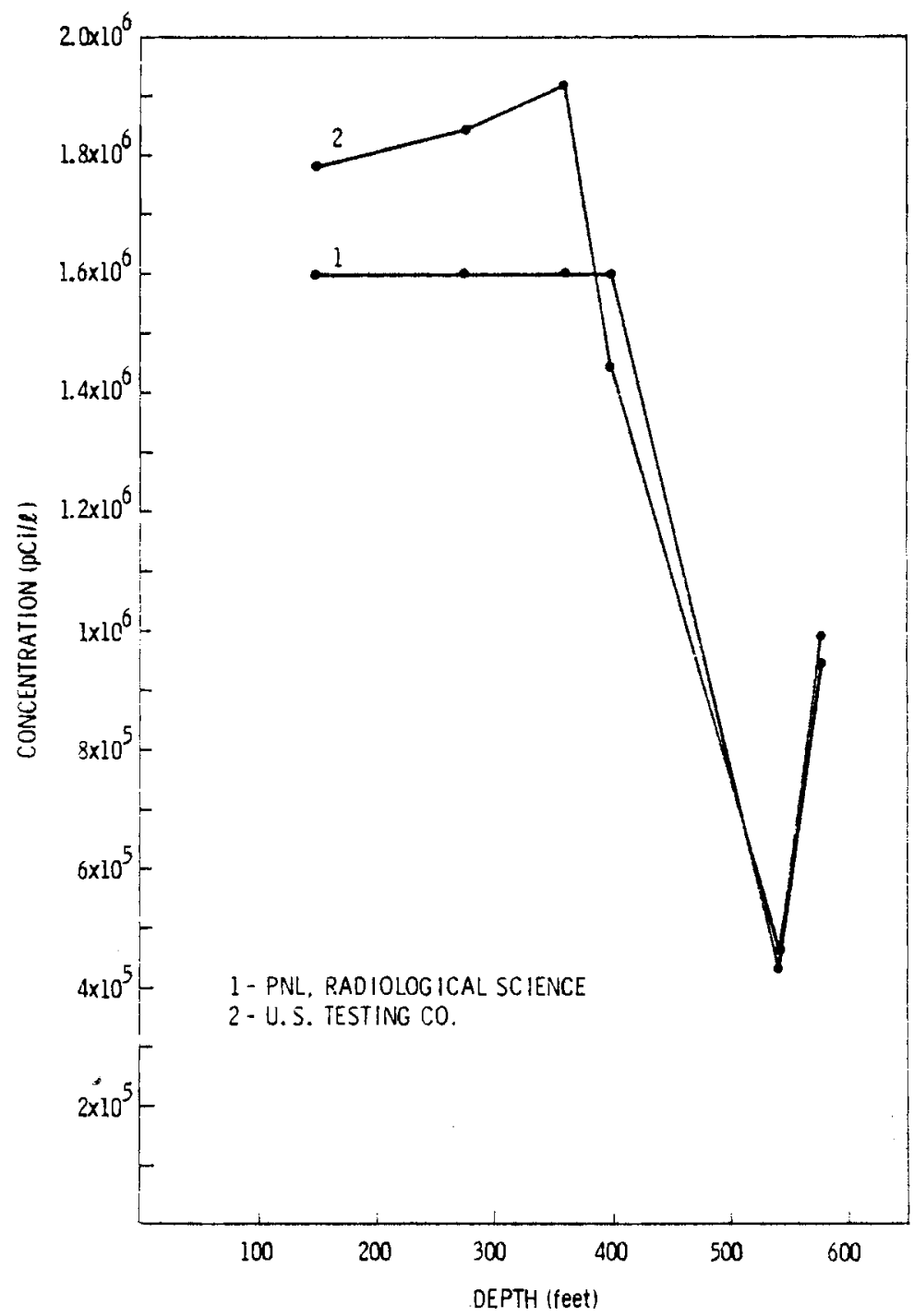

FIGURE A.7. Concentration of Tritium in We11 699-31-31 in 1976 


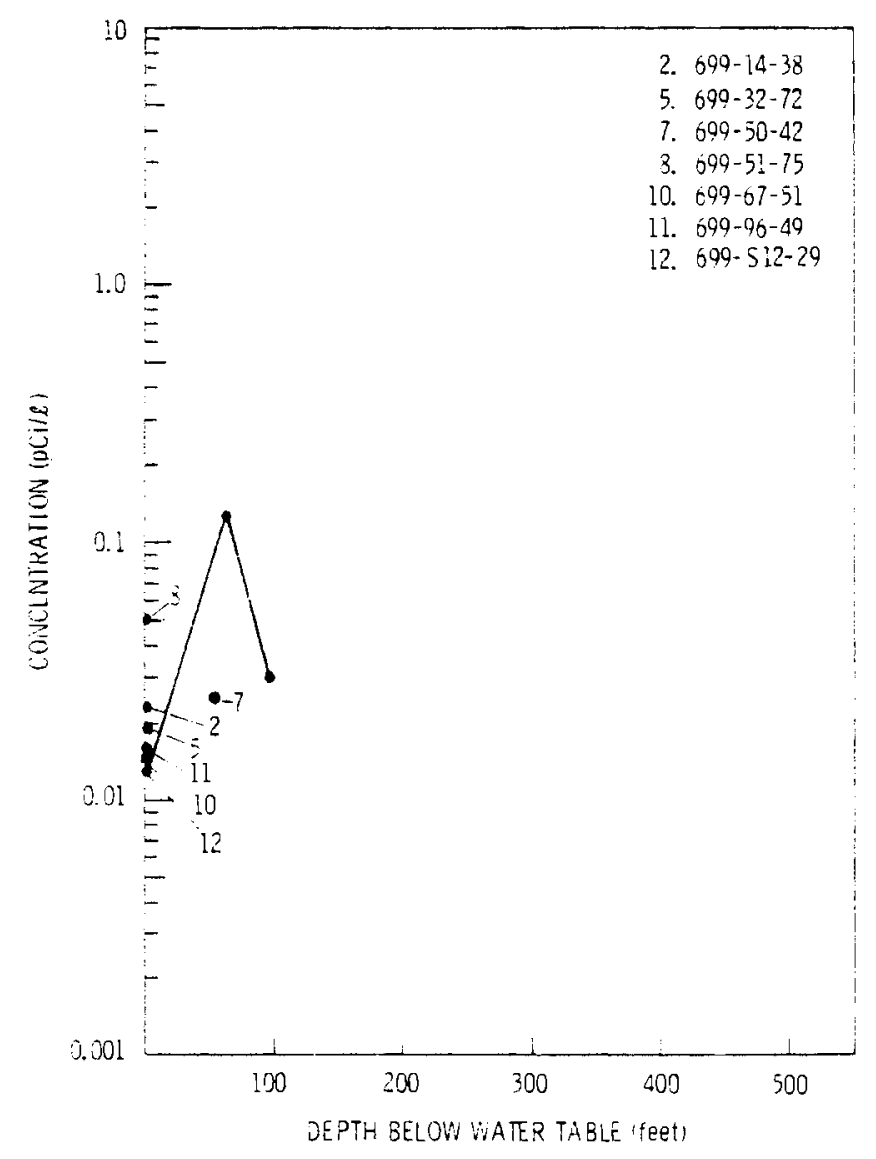

FIGURE A.8. Concentration of ${ }^{137} \mathrm{Cs}$ in Selected wells in 1977 

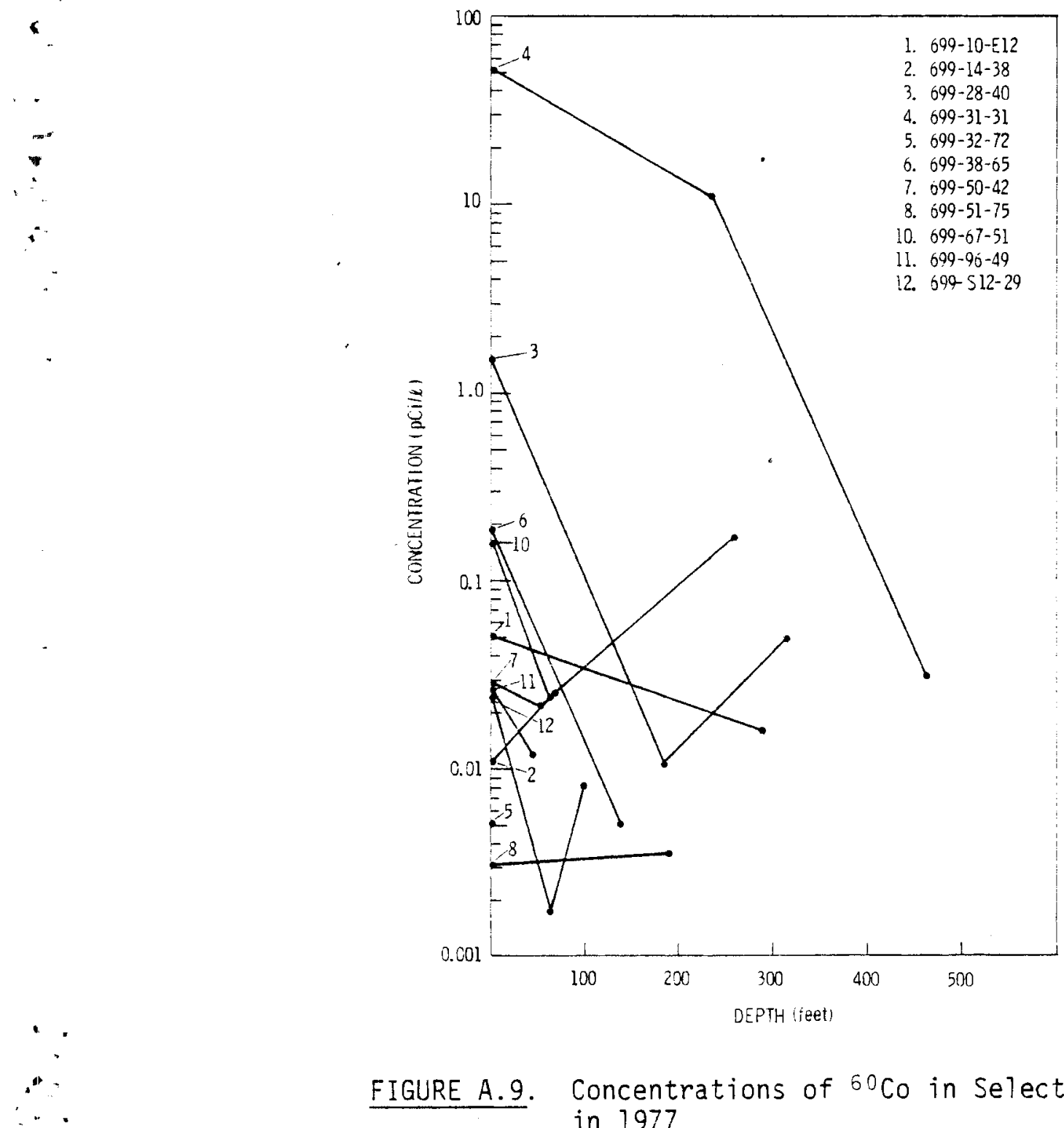

FIGURE A.9. Concentrations of $6{ }^{\circ}$ Co in Selected We11s in 1977 


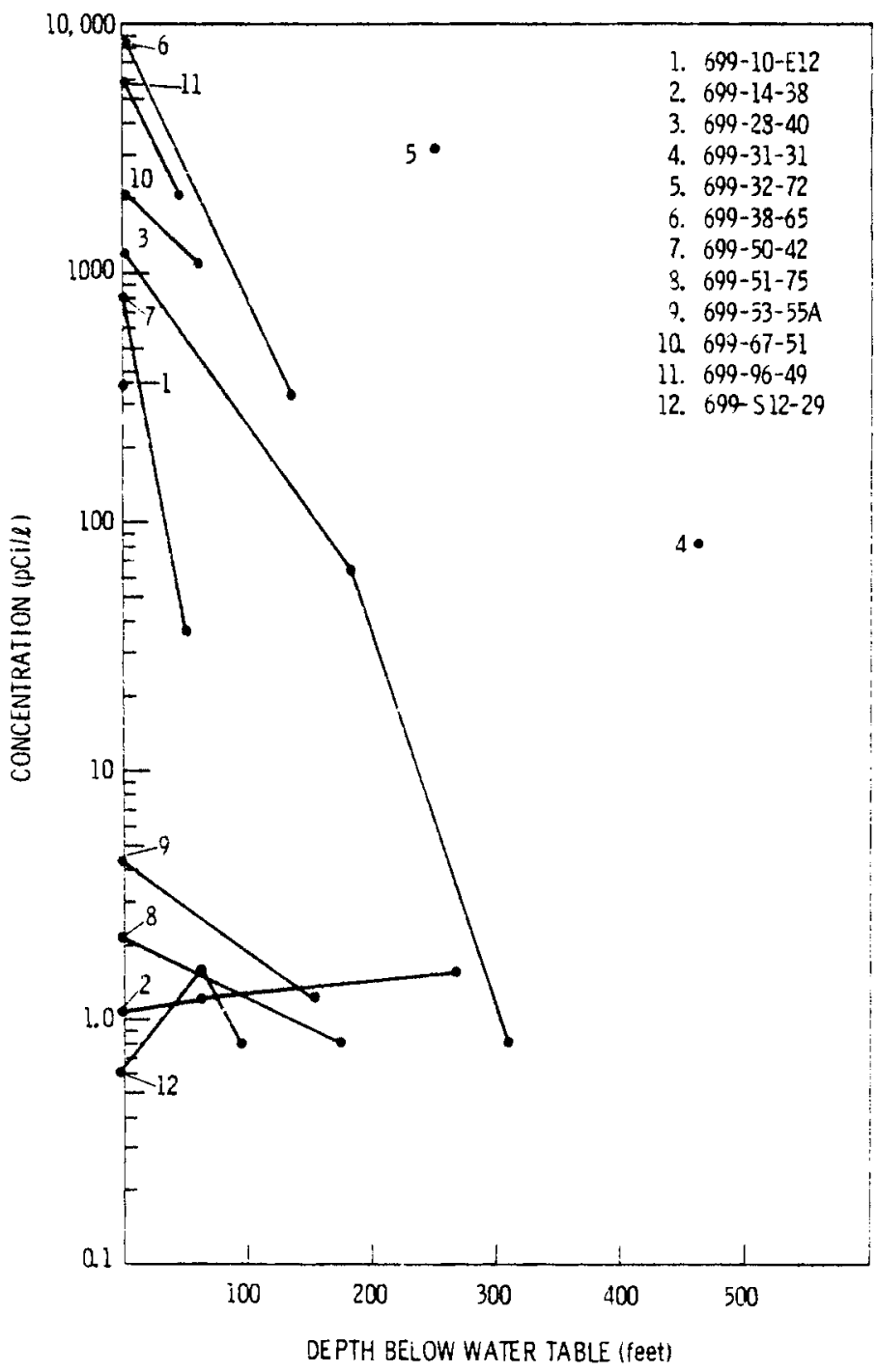

FIGURE A.10. Concentration of Tritium in Selected We11s in 1977 


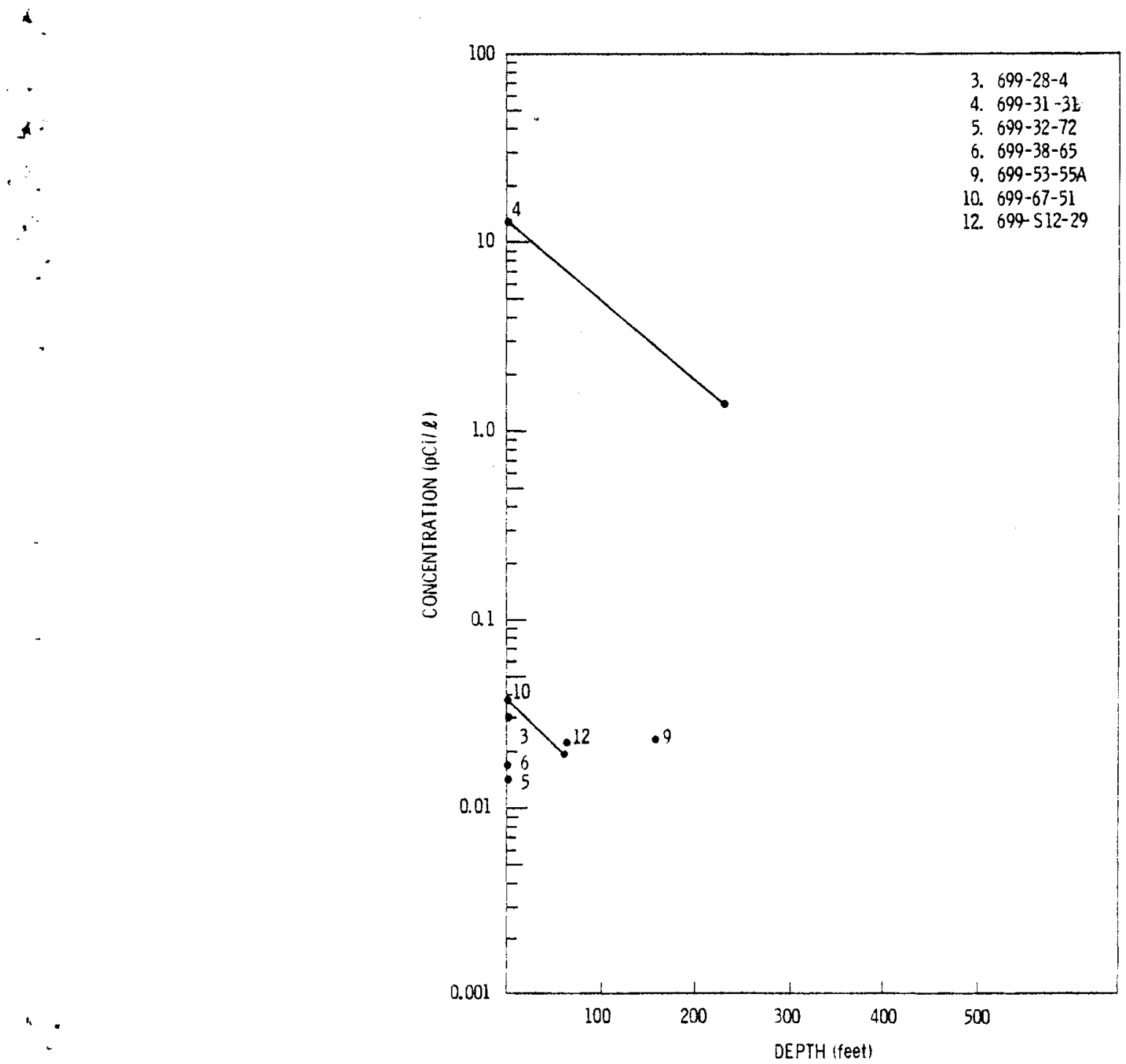

FIGURE A.11. Concentration of 206 Ru in Selected we 11 s in 1977 


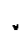




\section{DISTRIBUTION}

No. of

Copies

OFFSITE

A. A. Churm

DOE Chicago Patent Group

9800 South Cass Avenue

Argonne, IL 60439

D. H. Slade

DOE Division of Biomedical and Environmental Research Washington, DC 20545

G. W. Cunningham

DOE Div. of Waste Management, Production \& Reprocessing Washington, DC 20545

R. H. Engleken

NRC Directorate of Regional Operations, Region $V$ 1990 N. California Blvd., Suite 202

Walnut Creek, CA 94596

J. D. Griffith

Asst. Dir. of Reactor Safety

DOE Div. of Reactor Development and Technology

Washington, DC 20545

27 DOE Technical Information Center

R. E. Tiller

DOE Idaho Operations

Operational Safety Division

Idaho Falls, ID 83401

C. Sherman

DOE Headquarters Library

Mail Station G-043

Washington, DC 20545
No. of

Copies
H. Hollister

DOE Division of Operationa? and Environmental Safety

Washington, DC 20545

A. A. Schoen

DOE Division of Operational and Environmental Safety Washington, DC 20545

G. Facer

DOE Div. of Military Applications

Washington, DC 20545

W. J. Larkin

COE Nevada Operations Office

P. 0. Box 14100

Las Vegas, NV 89114

E. Cowan

Environmenta? Protection Agency Region $X$

Seattle, WA 98101

H. S. Jordan

Los Alamos Scientific Laboratory

Los Alamos, NM 87544

L. B. Day, Director

Oregon State Department of

Environmental Quality

1234 SW Morrison

Portland, OR 97205

G. Toombs

Oregon State Health Division

P. 0. Box 231

Portland, OR 97207 
No. of

Copies

M. W. Parratt

Oregon State Healich Division

P. 0. Box 231

Portland, OR 97207

R. R. Mooney

Washington State Department

of Social \& Health Services

1514 Smith Tower

Seattle, WA 98104

C. Lewis

Washington state Department of Social \& Health Services

P. 0. Box 1788, MS 56-1

01 ympia, WA 98504

T. Strong

Washington State Department of Social \& Health Services

P. 0. Box 1788, is 56-1

Olympia, WA 98504

R. C. Will

Washington State Department of Social \& Health Services

P. 0. Box 1788, MS 56-1

OTympia, WA 98504

G. L. Fiedler

Washington State Departiment of Ecology

Olympia, WA 98507

W. G. Hallauer

Washington State Department of Ecology

Olympia, WA 98504

G. Hansen

Washington State Department of Ecology

Olympia, WA 98504

E. Wallace

Washington State Department of Ecology

Olympia, WA 93504 ivo. of

Copies

J. C. Ebert

U. S. Geological Survey

1201 Pacific Avenue, Suite 600

Tacoma, WA 98402

R. A. Chitwood

Washington Public Power Supply System

3000 George Washington Way

Richland, WA 99352

D. D. Tilson

Washington Public Power Supply

System

3000 George Washington Way

Richland, WA 99352

K. R. Engstrom

City of Richland

Water and Sewer Department

505 Swift Blvd.

Richland, WA 99352

M. L. Smith

Exxon Nuclear

Horn Rapids Rd.

Richland, WA 99352

R. H. Poirier

Battelle Memorial Institute

505 King Avenue

Columbus, $\mathrm{OH} 43201$

R. C. Scott

EPA Office of Water Programs

760 Market Street

San Francisco, CA 94102

M. 0. Fretwel1

U. S. Geological Survey

345 Middlefield Rd.

Men 1o Park, CA 94025

J. B. Robertson

U. S. Geological Survey

345 Middlefield Rd.

Menlo Park, CA 94025 
No. of

Copies

R. D. Paris

Oregon State Health Division

1400 S.W. Fifth Avenue

Portland, OR 97201

ONSITE

13 DOE Richland Operations Office

P. F. X. Dunigan, Jr.

0. J. Elgert (2)

D. R. Elle

R. L. Ferguson

H. E. Ransom

R. E. Gerton

M. W. Tiernan

M. White (5)

11 Rockwe il Hanford Operations

R. C. Arnett

D. J. Brown

R. W. Bryce

K. Kover

A. L. Law

G. L. Hanson

F. A. Spane

J. V. Panesko (2)

B. J. Saueressig

RHO File

2 Hanford Environmental Health Fouridation

L. J. Maas

B. D. Reinert
No. of

Copies

5 United Nuclear Industries, Inc.

T. E. Dabrowski

A. E. Engler

E. A. Weakley

W. G. Westover

UNI File

5 Westinghouse Hanford Company
R. 0. Budd
G. Carpenter
R. B. Hall
R. W. Reed
G. K. Toyoda

40 Pacific Northwest Laboratory

G. E. Backman

J. R. Berry

P. J. Blumer

P. E. Bramson

D. B. Cearlock

J. P. Corley

P. A. Eddy (5)

J. R. Eliason

E. L. Hilty

J. R. Houston

L. R. Jaech

L. J. Kirby

H. V. Larson

V. L. McGhan

M. L. Miller

D. A. Myers (5)

J. R. Raymond (5)

B. D. Robertson

C. M. Unruh

R. W. Wallace

Technical Information (5)

Publishing Coordination (2)

P. E. Bramson - Historical File 


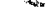

$\because$

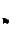

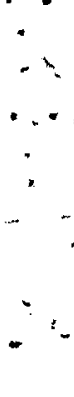

" 